\title{
Sea whip coral Leptogorgia virgulata in the Mid-Atlantic Bight: Colony complexity, age, and growth
}

\author{
Rebecca P Wenker ${ }^{\text {Corresp., } 1}$, Bradley G Stevens ${ }^{1}$ \\ ${ }^{1}$ Department of Natural Sciences, University of Maryland Eastern Shore, Princess Anne, Maryland, United States \\ Corresponding Author: Rebecca P Wenker \\ Email address: rwenker@umes.edu
}

Sea whip coral Leptogorgia virgulata are a common structural component of both natural and artificial hard-bottom reef habitats in the mid-Atlantic region and may serve as essential habitat for commercially valuable species. However, they are slow-growing, easily damaged, and especially vulnerable to damage by passive fishing gear such as pots and traps. Despite their potential importance, until recently, sea whips are generally understudied in this region. We examined the colony complexity, length, age, and growth of sea whips from four artificial reef sites in the mid-Atlantic region to gain a better understanding of their biology in the area. There were no significant differences in the bifurcation $\left(R_{b}\right)$ and tributary to source $(T / S)$ ratios between sites, with the $R_{b} \approx 3$ for all sites, indicating similar complexity between sites. The total length distribution was $8.3 \mathrm{~cm}$ to $85.3 \mathrm{~cm}$, and $50 \%$ of corals in the range of $34.2-56.4 \mathrm{~cm}$. Age, estimated from annual growth ring counts, ranged from 2 to $15 \mathrm{y}$, with $50 \%$ of corals in the range of 6 to $8 \mathrm{y}$. The large proportion of middle-sized and middle-aged corals suggests episodic recruitment. Age-length keys showed the trend of age increasing with total coral length, and a von Bertalanffy growth model demonstrated size-dependent growth following the equation: $E[L \mid t](\mathrm{cm})=86.1\left(1-\mathrm{e}^{-0.14(\mathrm{t}-1.44)}\right)$. This is the first study providing such data for sea whips in the coastal mid-Atlantic region, and the baseline created will be a useful reference to study changes over time. 
1

2 Sea whip coral Leptogorgia virgulata in the Mid-Atlantic

3 Bight: Colony complexity, age, and growth

4

5

6

7

8

9

${ }^{1}$ Department of Natural Sciences, University of Maryland Eastern Shore, Princess Anne, 10 Maryland, USA

11

Corresponding Author:

13 Rebecca Wenker ${ }^{1}$

14 University of Maryland Eastern Shore, 1 Backbone Road, Princess Anne, Maryland, 21853, 15 USA

16 Email address: rwenker@umes.edu

17

18

19

20

21

22

23

24

25

26

27

28

29

30

31

32

33

34

35

36 
37

38

39

40

41

42

43

44

45

46

47

48

49

50

51

52

53

54

55

56

57

58

59

60

61

62

63

64

65

66

67

68

69

70

71

72

73

74

75

76

\section{Abstract}

Sea whip coral Leptogorgia virgulata are a common structural component of both natural and artificial hard-bottom reef habitats in the mid-Atlantic region and may serve as essential habitat for commercially valuable species. However, they are slow-growing, easily damaged, and especially vulnerable to damage by passive fishing gear such as pots and traps. Despite their potential importance, until recently, sea whips are generally understudied in this region. We examined the colony complexity, length, age, and growth of sea whips from four artificial reef sites in the mid-Atlantic region to gain a better understanding of their biology in the area. There were no significant differences in the bifurcation $\left(R_{b}\right)$ and tributary to source $(T / S)$ ratios between sites, with the $\mathrm{R}_{\mathrm{b}} \approx 3$ for all sites, indicating similar complexity between sites. The total length distribution was $8.3 \mathrm{~cm}$ to $85.3 \mathrm{~cm}$, and $50 \%$ of corals in the range of 34.2-56.4 cm. Age, estimated from annual growth ring counts, ranged from 2 to $15 \mathrm{y}$, with $50 \%$ of corals in the range of 6 to $8 \mathrm{y}$. The large proportion of middle-sized and middle-aged corals suggests episodic recruitment. Age-length keys showed the trend of age increasing with total coral length, and a von Bertalanffy growth model demonstrated size-dependent growth following the equation: $\mathrm{E}[\mathrm{L} \mid \mathrm{t}](\mathrm{cm})=86.1\left(1-\mathrm{e}^{-0.14(\mathrm{t}-1.44)}\right)$. This is the first study providing such data for sea whips in the coastal mid-Atlantic region, and the baseline created will be a useful reference to study changes over time.

\section{Introduction}

Cold-water corals are an important contributor to benthic habitat complexity on continental shelves and slopes, canyons, seamounts, oceanic banks, and ocean ridges (Freiwald et al. 2004). They have also been observed to colonize man-made structures, such as artificial reefs or shipwrecks (Steimle and Zetlin 2000; Freiwald et al. 2004). These coral habitats often serve as biodiversity hotspots and are used by other species for numerous purposes, including nurseries, feeding and spawning grounds, and refuge sites (Freiwald et al. 2004; Foley et al. 2010; Watling et al. 2011; Baillon et al. 2012). However, these communities have been negatively impacted by fishing activities such as bottom trawling, bottom-set gillnets and longlines, pots, and traps (Van Dolah et al. 1987; Freiwald et al. 2004; Watling et al. 2011; Schweitzer et al. 2018), which can inflict structural damage to the coral or completely remove them from the seafloor.

In the Mid-Atlantic Bight (MAB), ranging from Massachusetts to North Carolina on the U.S. east coast, benthic habitats are primarily flat and homogenous topography composed of sand and mud bedforms. Within this region, hard-bottom reef habitats are scarce, patchy, and widely scattered (Steimle and Zetlin 2000). Reef habitats vary in composition and include both natural rocky bottom and mud outcrops as well as anthropogenic structures such as shipwrecks, pipes, lost cargos, and cable cars that form artificial reefs (Steimle and Zetlin 2000). Due to the relative infrequency of natural hard-bottom substrate, introduced or artificial reef habitat is most likely a significant source of habitat complexity. Both natural and artificial reef structures provide multi-dimensionality and can support biological communities that the surrounding soft- 
77 bottom habitat cannot, including mussels, crabs, lobsters, corals, sponges, and numerous fish

78

79

80

81

82

83

84

85

86

87

88

89

90

91

92

93

94

95

96

97

98

99

100

101

102

103

104

105

106

107

108

109

110

111

112

113

114

115

116 species (Sedberry and Van Dolah 1984; Steimle and Figley 1996; Steimle and Zetlin 2000; Fabrizio et al. 2013; Ross et al. 2016). Due to the high utilization of natural and artificial reef habitat by fish species, mid-Atlantic reefs are often well-known and targeted by recreational and commercial fisheries (Steimle and Zetlin 2000).

In the Delaware, Maryland, and Virginia (Delmarva) region of the MAB the sea whip Leptogorgia virgulata is a common component of natural and artificial hard-bottom reefs (Steimle and Zetlin 2000; Cullen and Stevens 2017; Schweitzer et al. 2018; Schweitzer and Stevens 2019). These corals can be found along the North American Atlantic coast, and have been observed at depths of 2-59 meters (Bayer 1961; Gotelli 1988; DeVictor and Morton 2010; Packer et al. 2017). Sea whips are non-reef building corals, but have a stiffened axial skeleton and a 3-dimensional structure with branches arranged around a central axis, adding additional height to reef substrate (Bayer 1961; Mitchell et al. 1993; DeVictor and Morton 2010). Growth rings are deposited into this axial rod and assumed to be annual, enabling age estimation (Grigg 1974; Mitchell et al. 1993). Notably, the structural complexity provided by sea whips and the biotic community associated with them may make these corals a significant habitat for many commercially and recreationally valuable species (Van Dolah et al. 1987; Ruppert and Fox 1988; Steimle and Figley 1996; Able and Fahay 1998; Wicksten and Cox 2011; Cullen and Stevens 2017). These include species like black sea bass Centropristis striata, tautog Tautoga onitis, and lobster Homarus americanus in the Delmarva region, and snapper Lutjanus spp., grouper Epinephelus spp., and porgy Calamus spp. in the South Atlantic Bight (Van Dolah, Wendt, and Nicholson 1987; Steimle and Figley 1996; Able and Fahay 1998; Cullen and Stevens 2017). Additionally, Schweitzer and Stevens (2019) found fish abundance to positively correlate with sea whip coverage on artificial Delmarva reef habitats, and that sea whips were the only biogenic structure in the study significantly related to fish abundance.

Several studies have also indicated that healthy sea whips produce a strong chemical defense system, preventing the attachment, settlement, and fouling by epibionts (Targett et al., 1983; Standing et al. 1984; Gerhart et al. 1988; Clare et al., 1999). Sea whips in the Delmarva region show evidence of damage and overgrowth by fouling organisms (personal observation; Schweitzer et al. 2018; Schweitzer and Stevens 2019). This includes overgrowth by organisms such as mussels, bryozoans, ascidians, and sponges, as well as damaged and stripped tissue. The presence of overgrowth and fouling could suggest that the underlying coral tissue has been damaged or killed either by natural causes or impacts with fishing gear, and the coral's chemical defense system impaired.

Despite their potential importance to commercially valuable fish and shellfish species, sea whips are generally understudied in the western Atlantic, and little is known about the local natural and artificial reefs nor the sea whip colonies that occupy them. No standard or baseline information exists for comparison in case of major changes to this habitat, whether caused by human or natural disturbance. For example, there is currently no information regarding growth rates, effects of damage or fouling on growth and mortality, or rates of recovery from damage. 
117

118

119

120

121

122

123

124

125

126

127

128

129

130

131

132

133

134

135

136

137

138

139

140

141

142

143

144

145

146

147

148

149

150

151

152

153

154

155

In response to this lack of information, this study was undertaken to provide new insights into the biology of sea whip corals. The goals of this project were to determine colony complexity, age, and growth rates of sea whips from four artificial reef sites in the mid-Atlantic region, in order to gain a better understanding of reef ecology in this understudied region.

\section{Materials \& Methods}

\section{Study sites}

Sea whips were collected from four artificial hard-bottom reef sites located approximately $16 \mathrm{~km}$ offshore of Ocean City, MD (Table 1; Fig. 1). Depth differed between sites, with Memorial Barge being 17-20 m, South Ledges 17-21 m, Sussex Wreck 24-26 m, and Boom Wreck 21-24 m (Table 1). Memorial Barge was placed on the sea floor in 1993, South Ledges in 2000, Sussex Wreck in 1995, and Boom Wreck in an unknown year. Samples were taken from the Memorial Barge on October 3, 2016 and August 7, 2017, South Ledges on August 11, 2017, Sussex Wreck on August 10, 2018, and Boom Wreck on October 1, 2018.

\section{Sample measurement and collection}

All sample collections were made via regular scuba diving. Though sea whips are not a managed species, approval for their collection was obtained from the National Oceanic and Atmospheric Administration. A total of 102 sea whips were collected; 24 from Memorial Barge, 26 from South Ledges, 29 from Sussex Wreck, and 23 from Boom Wreck (Table 1). At each site, two dives were conducted per each sampling day. On the first dive, scuba divers measured size frequency of the corals present using a systematic random sampling approach. This was done by stretching out a 50 meter tape measure from a random starting point within $1 \mathrm{~m}$ from the edge of the habitat along the longest dimension of the habitat, and selecting the specimen nearest to every $0.5 \mathrm{~m}$ mark along the tape. Coral colonies were stretched out, and their height (total length, TL) was marked with a pencil on a section of $1 / 2$ inch diameter PVC pipe marked at $1 \mathrm{~cm}$ intervals.. A total of 119 corals were measured in-situ; 29 from Memorial Barge, 28 from South Ledges, 31 from Sussex Wreck, and 31 from Boom Wreck (Table 1). The length of the transect differed per site due to the varying size of each reef structure and abundance of sea whips, though we tried to stretch the tape across areas with higher densities of sea whips in order to achieve an acceptable sample size.

On the second dive, colonies were selected for estimation of age and colony complexity in a stratified manner. We attempted to sample a similar number of small, medium, and large colonies, based on the initial size frequency analysis. Specimens were collected by either removing the entire colony with its holdfast intact if possible, or by cutting the basal stalk at the point closest to the holdfast with bone cutters. Sampled colonies were placed in a large mesh bag for transport to the surface.

\section{Colony complexity}


156

157

158

159

160

161

162

163

164

165

166

167

168

169

170

171

172

173

174

175

176

177

178

179

180

181

182

183

184

185

186

187

188

189

190

191

192

193

194

195

The total length of all collected coral specimens was measured to the nearest $\mathrm{mm}$, and all branches were counted and labeled for branching analysis. Two measures of colony complexity were obtained for each collected colony: a bifurcation ratio $\left(\mathrm{R}_{\mathrm{b}}\right)$, and a tributary to source ratio $(\mathrm{T} / \mathrm{S})$.

The $R_{b}$ is the ratio of the number of branches of a given order to the number of branches of the next higher order, a technique originally used to describe stream networks (Strahler 1952, Brazeau and Lasker 1988). Different branch levels were assigned, with the most distal branches being primary, the union of two primary branches forming a secondary, two secondary branches connecting to form a tertiary, etc. (Fig. 2). The $\mathrm{R}_{\mathrm{b}}$ is then obtained by regressing the log of number of branches versus branch order, and calculating the antilog of the slope of the regression line. Branching networks that display perfectly dichotomous branching have $a R_{b}$ of 2 , and this value increases as branches that do not increase the order of the system are added. A benefit to this ordering technique is that branches with similar functions are grouped in the same order (Mitchell et al. 1993; Brazeau and Lasker 1988). For example, primary branches tend to have younger, non-reproductive polyps, whereas older, reproductive polyps are more frequently found on secondary and tertiary branches (Brazeau and Lasker 1988). We calculated the $\mathrm{R}_{\mathrm{b}}$ for each colony, and an average for each site.

While the $\mathrm{R}_{\mathrm{b}}$ focuses primarily on overall colony complexity, the T/S ratio is more sensitive to differences at each level of branching. The T/S ratio distinguishes between branches which do or do not increase the order of the system (Mock 1971). A branch that joins another branch of equal order is called a "source" branch, while branches that join a branch of higher order are "tributary" branches (Fig. 2) (Mock 1971; Brazeau and Lasker 1988). Following the methods of Brazeau and Lasker (1988) and Mitchell et al. (1993), we calculated the T/S ratios of primary and secondary branches in each colony by dividing the number of tributary branches by the number of source branches. We then calculated an average primary and secondary T/S ratio per site.

The mean length of in-situ and collected corals were each compared between sites with a One-way ANOVA to test the null hypothesis of equality between sites. The $\mathrm{R}_{\mathrm{b}}$ and $\mathrm{T} / \mathrm{S}$ ratios of collected corals were each compared between sites with a One-way ANOVA (R function aov). Total length distributions of in-situ corals and collected corals were each compared between sites with two-sample Kolmogorov-Smirnov (KS) tests (R Core Team 2017). Only two sites can be compared simultaneously with a KS test, so 6 tests were conducted to compare all the sites for both in-situ and lab measured corals. We adjusted the critical $P$-value $(\alpha)$ accordingly using the Bonferroni correction method, dividing 0.05 by 6 to get a new critical $\alpha$ of 0.008 .

\section{Age analysis}

After air-drying colonies in the lab until completely dry, short $(\approx 10 \mathrm{~mm})$ pieces of the axial skeleton were cut from the base of each coral, and placed in a single $2 \times 3 \times 1 \mathrm{~cm}$ well within a silicon tray. Prior to embedding, the molds were sprayed with a silicon spray and left to dry. The epoxy solution was mixed for at least a minute, and then poured over the coral sections in 
196 the wells until it covered them completely. The epoxy resin blocks were left to dry for at least 8 197 hours, and then sliced with a diamond bladed saw into sections of approximately $18 \mu \mathrm{m}$

198

199

200

201

202

203

204

205

206

207

208

209

210

211

212

213

214

215

216

217

218

219

220

221

222

223

224

225

226

227

228

229

230

231

232

233

234

235 thickness (range 15-22 $\mu \mathrm{m}$ ). Five consecutive sections of each basal piece were mounted on glass slides with crystal bond and photographed under a stereo-zoom microscope. Photos were then viewed in Adobe Photoshop to estimate age by counting annuli rings from the center outwards (Fig. 3). Preliminary analysis indicated that age estimates did not vary between sequential sections, and because the low quality of some sections made them unusable, we chose to analyze the best (i.e. clearest) section from each colony. Criteria for rings included either of two criteria (Mitchell et al. 1993): 1) A concentric band darker than the surrounding tissue, or; 2) A change in density or color of the axial rod in the inner region of the cross section. Growth rings were counted out to the growing edge of the coral, this edge not being counted as a ring unless it met the previous criteria.

The in-situ total length measurements were used to assign putative ages to in-situ corals via the Isermann-Knight Method using the age-length key generated from the collected corals (Ogle 2016), described in the following growth methods section. The functions required to assign these ages are included in the FSA, dplyr, and nnet packages in R (Venables and Ripley 2002; R Core Team 2017; Ogle 2016, 2018; Wickham et al. 2018).

Mean ages of in-situ and collected corals were compared between sites using a One-way ANOVA (R function aov), and a Tukey HSD test was used to determine if any significant differences occurred between sites. Age distributions were compared between sites using twosample KS tests with a Bonferroni adjusted critical $\alpha$ of 0.008 (R Core Team 2017). Age rings in coral sections were independently counted by two observers to estimate bias (Grigg 1974). If the values differed between readers the average was used. The presence of bias and the proportional agreement between readers was evaluated in R using age-bias plots and three symmetry tests, including McNemar, Evans and Hoenig, and Bowker (Ogle 2016, 2018). All three tests focus on whether an age-agreement table is symmetric around the main diagonal; however, the tests differ in how they gather the data for comparison. Each test produces estimates of the degrees of freedom, a chi-squared value, and a $P$ value. The null hypothesis for these tests is that no asymmetry (or bias) occurs within the age estimates. The McNemar test uses a maximally pooled approach by adding squared values above and below the diagonal agreement line and determining if the sums are equal. It doesn't take into account where the values are relative to the main diagonal other than above or below. In contrast, the Evans and Hoenig test uses a diagonally pooled approach, which tests for differences in values pooled from off-diagonals that are the same "distance" from the main diagonal. Bowker's test calculates chi-squared without any pooling, and tests for differences between cells that are in the same relative positions above and below the main diagonal.

Precision of the data was evaluated using three indices: percent agreement (PA), average percent error (APE) and the average coefficient of variation (ACV). The APE assumes the standard deviation of age is proportional to the mean age for individual corals. The ACV is a measure of the dispersion of data points in a data series around the mean, or the ratio of standard 
236 deviation to the mean, and does not have the assumption mentioned for APE. For both APE and

237

238

239

240

241

242

243

244

245

246

247

248

249

250

251

252

253

254

255

256

257

258

259

260

261

262

263

264

265

266

267

268

269

270

271

272

273

274

275

$\mathrm{ACV}$ lower values indicate higher agreement, with $\mathrm{ACV}<5 \%$ indicating high precision.

\section{Growth}

Age-length keys, observed and smoothed, were constructed using the total length and age data from collected corals. These keys show the proportion of ages (ring counts) within bins of 5 $\mathrm{cm}$ total length. Observed age-length keys were constructed using raw data, whereas smoothed age-length keys use a multinomial linear regression to model proportions at each age for each length category. The predicted proportion of coral at age for any one length interval is influenced by both the data for that interval and age as well as by data for other intervals and ages resulting in predicted values that follow a smooth curve. Coral growth rate was determined by examining the relationship between length and age, and fitting that age-length data to a von Bertalanffy growth model using the following equation: $\mathrm{E}[\mathrm{L} \mid \mathrm{t}]=\mathrm{L}_{\infty}\left(1-\mathrm{e}^{-\mathrm{K}(\mathrm{t}-\mathrm{t} 0)}\right)$ where $\mathrm{E}[\mathrm{L} \mid \mathrm{t}]$ is the expected or average length at age $\mathrm{t}, \mathrm{L}_{\infty}$ is the asymptotic average length, $\mathrm{K}$ is the Brody growth rate coefficient or exponential rate of approach to $\mathrm{L}_{\infty}\left(\mathrm{yr}^{-1}\right)$, and $\mathrm{t}_{0}$ is the age when mean length is zero (model artifact) (Beverton and Holt 1957). Confidence intervals for parameters in non-linear models, like the von Bertalanffy model, are best found through bootstrapping methods and not the model summary. To do this, we followed the methods of Ogle (2016) using the nlstools package (Baty et al. 2015). Von Bertalanffy models have been used to study the growth patterns of other gorgonian coral species (Grigg 1974; Mistri and Ceccherelli 1993, 1994; Goffredo and Lasker 2006; Munari et al. 2013), as well as corals with sizedependent growth (Chadwick-Furman et al. 2000; Goffredo et al. 2004).

The functions required to construct age-length keys are included in the FSA, dplyr, and nnet packages in R (Venables and Ripley 2002; R Core Team 2017; Ogle 2016; Ogle 2018; Wickham et al. 2018). The functions required to perform growth analyses and bootstrapping methods in R are contained in the FSA and nlstools packages (Baty et al. 2015; R Core Team 2017; Ogle 2016, 2018).

\section{Results}

\section{Colony complexity}

There was no significant difference in mean length and total length distributions between sites for both in-situ (One-way ANOVA, $F(3,115)=1.84, p=0.14$; KS test $\mathrm{x} 6$, all $p>0.008$ ) and collected corals (One-way ANOVA $F(3,98), p=0.71$; KS test x 6 , all $p>0.008$ ). Therefore, we pooled them together into a length-frequency figure containing all 119 corals measured in-situ and the 102 corals collected (Fig. 4). The mean length of in-situ sea whips was $48.6 \pm 1.8 \mathrm{~cm}$ (mean $\pm \mathrm{SE}$ ), with total length ranging from $7.5 \mathrm{~cm}$ to $100.2 \mathrm{~cm}$ (Fig. 4), and $50 \%$ of in-situ sea whips were in the range of 33.7-61.8 cm. The mean height of collected sea whips was $46.9 \pm 1.7$ $\mathrm{cm}$. Total length ranged from $8.3 \mathrm{~cm}$ to $85.3 \mathrm{~cm}$, with $50 \%$ of corals in the range of $34.2-56.4 \mathrm{~cm}$ (Fig. 4). Total length frequency of both collected and in-situ sea whips per site are illustrated in 
276 Figure 5. No significant differences in the bifurcation $\left(\mathrm{R}_{\mathrm{b}}\right)$ ratios of $L$. virgulata were found 277 between sites (One-Way ANOVA, $F(3,97)=0.0597, p=0.81$ ) (Table 2). The average $\mathrm{R}_{\mathrm{b}}$ ratios of 278 approximately 3 for all sites indicated that for each branch of a given order, there are 279 approximately three branches in the next lower order. For example, for every tertiary branch 280 there are three secondary branches, and for every secondary branch there are three primary 281 branches. There was also no significant difference found between tributary to source (T/S) ratios 282 in primary (One-way ANOVA, $F(3,100)=3.317, p=0.072$ ) and secondary (One-way ANOVA, $283 F(3,97)=0.348, p=0.556$ ) branches between sites (Table 2 ).

284

285

286

287

288

289

290

291

292

293

294

295

296

297

298

299

300

301

302

303

304

305

306

307

308

309

310

311

312

313

314

315

\section{Age analysis}

Neither mean age nor age distribution of collected corals differed significantly between sites (One-way ANOVA, $F(3,100), p=0.55$; KS test x 6, all $p>0.008$ ). Therefore, data for collected corals from all four sites were grouped together for further analysis (Fig. 6). Estimated age of collected sea whips ranged from 2 to $15 \mathrm{y}$, with $50 \%$ in the range of 6 to $8 \mathrm{y}$. The distribution of assigned ages for in-situ corals was not significantly different between sites (KS test $\mathrm{x} 6$, all $p>0.008$ ), however there was a significant difference in their mean assigned ages (One-way ANOVA, $F(3,115), p=0.013)$. Further analysis with a post hoc Tukey HSD test showed that mean age differed significantly $(p=0.008)$ between the Memorial Barge $(6.3 \mathrm{y})$ and South Ledges ( $8.3 \mathrm{y}$ ) sites, with mean ages for other sites not significantly different. Assigned ages for in-situ corals $>85 \mathrm{~cm}$ are also most likely underestimated (see Growth section below). Age frequency of both collected and in-situ sea whips per site are illustrated in Figure 7. Three tests of symmetry showed no systematic bias between readers (McNemar $p=0.64$, Evans and Hoenig $p=0.64$, Bowker $p=0.38$ ) (Table 3). $P$-values $>0.05$ for each test indicate that the null hypothesis has not been rejected, therefore no significant asymmetry was observed. Indices of precision show that percent agreement (PA) between readers was $82.35 \%$, with the remaining $18 \%$ differing by only 1 year. The average percent error (APE) was $1.2 \%$, and the average coefficient of variation (ACV) was $1.7 \%$, therefore our age counts can be considered precise $(\mathrm{ACV}<5 \%)$.

\section{Growth}

The age-length keys generated from the pooled coral data show the trend of age increasing with total coral length (Fig. 8). In the observed age-length key there are portions that seem to contradict the overall trend, such as the age 7 and 8 corals in the $65 \mathrm{~cm}$ interval following the age 9-13 corals in the three previous intervals. This is a common issue with observed age-length keys, and can be due to highly variable ages within a length interval and small sample sizes in some length intervals. The smoothed age-length key, which applies a multinomial logistic regression model fit to all length intervals and ages, addresses those issues and more clearly shows the trend of increased age with total coral length (Fig. 8).

Coral growth was determined by relating age estimates to total coral length in a von Bertalanffy growth model (Fig. 9), using all 102 corals collected. Our model demonstrates size- 
316 dependent growth, and the parameters were calculated to be: $\mathrm{L}_{\infty}=86.1 \mathrm{~cm}(95 \% \mathrm{CI}: 66.7-219.6$, $317 P=0.000003), \mathrm{K}=0.14 \mathrm{yr}^{-1}(0.028-0.26, P=0.029)$, and $\mathrm{t}_{0}=1.44 \mathrm{y}(-1.37-2.53, P=0.098)$. This

318 results in the equation

$319 \mathrm{E}[\mathrm{L} \mid \mathrm{t}](\mathrm{cm})=86.1\left(1-\mathrm{e}^{-0.14(\mathrm{t}-1.44)}\right)$

320 where $E[\mathrm{~L} \mid \mathrm{t}]$ represents length at age $t$. Therefore, the curve reaches an asymptotic mean length

321 of $86.1 \mathrm{~cm}$ at the exponential rate of approach of $0.14 \mathrm{yr}^{-1}$, with corals about 20 years in age. The

322 age at which mean length is 0 , or $t_{0}$, is 1.44 years. However, $t_{0}$ is a modeling artifact and has little

323 biological significance. The maximum observed length of in-situ corals $(100.2 \mathrm{~cm})$ was greater

324 than the largest length category in the age-length keys $(85 \mathrm{~cm})$. Furthermore, the value of $\mathrm{L}_{\infty}=$

32586.1 is intended to estimate the mean size of the largest corals, not the maximum size. Therefore,

326 when assigning ages to the in-situ corals the last length category was treated as all-inclusive.

327 Subsequently, the ages of in- situ corals $>85 \mathrm{~cm}$ are most likely underestimated.

328

329

\section{Discussion}

330

331

The mean height of collected sea whips in our study was $46.9 \pm 1.7 \mathrm{~cm}$, with a total length distribution of $8.3 \mathrm{~cm}$ to $85.3 \mathrm{~cm}$, and $50 \%$ of corals in the range of 34.2 to $56.4 \mathrm{~cm}$. In

332 contrast, L. virgulata colonies studied by Mitchell et al. (1993) in the Gulf of Mexico had a mean

333 size of $18.9 \mathrm{~cm}$ and none exceeded $32.5 \mathrm{~cm}$ in height. Mitchell et al. (1993) study site was only

334

335

336

337

338

339

340

341

342

343

344

345

346

347

348

349

350

351

352

353

354

355 1-1.5 $\mathrm{m}$ in depth and exposed to more frequent wave action and subsequent sand scouring than our sites which were at depths of 17-26 m. This could have prevented coral growth to larger heights. However, strong and tall communities of gorgonian corals have been documented on habitats exposed to strong surf (Kinzie 1973; Birkeland 1974; Sanchez et al. Zea 1997; Gomez et al. 2014).

\section{Colony complexity}

The average bifurcation ratio $\left(\mathrm{R}_{\mathrm{b}}\right)$ equaled approximately 3 for all study sites, indicating that for each branch of a given order there are approximately three branches in the next lower order. This coincides with the $\mathrm{R}_{\mathrm{b}}$ of 3.1 that Mitchell et al. (1993) found for the sea whips in their study, suggesting this may be a characteristic of the species. In many arboreal gorgonians, the distal portion of first order branches include many young, nonreproductive polyps while older, reproductive polyps are more numerous on secondary and tertiary branches (Brazeau and Lasker 1988).

There was no significant difference found between tributary to source (T/S) ratios in primary and secondary branches between sites. Larger primary T/S ratios at Memorial Barge and South Ledges indicate that there are more primary than secondary tributary branches in the colonies at each site, which may explain their "bushier" appearance, however it doesn't contribute to changing the overall colony complexity as indicated by the bifurcation ratio. The lower primary $\mathrm{T} / \mathrm{S}$ ratios at the deeper Sussex and Boom Wreck sites indicate fewer accessory (tributary) branches, but the difference was not significant. This pattern was also seen in Brazeau and Lasker's (1988) study, which looked at the colony complexity of two arborescent gorgonian 
356

357

358

359

360

361

362

363

364

365

366

367

368

369

370

371

372

373

374

375

376

377

378

379

380

381

382

383

384

385

386

387

388

389

390

391

392

393

394

395

species, Plexaura homomalla and Plexaura flexuosa, at shallow and deep sites. They found primary and secondary T/S ratios to decrease significantly with depth, leading to the "bushier" appearance of corals at the shallow site (Brazeau and Lasker 1988). Though the differences were not significant in our study, the reoccurrence of the pattern suggests that the colony complexity of arborescent gorgonian corals, like $L$. virgulata, can change with depth. In corals containing zooxanthellae, this change in colony morphology could serve to reduce self-shading at lower light levels (Brazeau and Lasker 1988). Like other cold-water corals, however, L. virgulata lacks zooxanthellae (Roberts et al. 2006). Therefore, morphological plasticity in this species could be due to other depth-related factors, such as wave stress, current intensity, food density, and predation (Lasker et al. 1983; Dai and Lin 1993; West et al. 1993; Sanchez et al. 1997).

\section{Age Analysis}

Our sea whip samples had an age range of 2 to $15 \mathrm{y}$, with $50 \%$ in the range of 6 to $8 \mathrm{y}$. Agreement on ring counts between readers was high, and there was no systematic bias displayed in ageing by either reader. There was more disagreement at greater ages, most likely because rings towards the outer edge of the coral tend to be smaller in width and closer together (Grigg 1974), making it harder to distinguish between them. However, estimates never differed by more than one year.

Despite our systematic approach to sampling and L. virgulata's annual reproductive season (Adams 1980), we observed very few juveniles and a large proportion of middle-age colonies. This is similarly expressed in the size frequency of corals collected and those measured in-situ, which show fewer colonies in the smaller size classes and a larger proportion in the midsize classes. The dominance of medium-aged $L$. virgulata colonies is consistent with episodic recruitment, with the high frequency of middle-age colonies representing a past "pulse" in recruitment (Munari et al. 2013). This episodic recruitment may be due to environmental factors influencing the mortality and settlement of coral larvae, newly settled recruits, and/or juvenile colonies. Smaller gorgonian corals have been observed to have higher mortality rates than those in larger size classes (Grigg 1977; Gotelli 1991; Gomez et al. 2014). Yoshioka (1994) observed this trend in gorgonian Pseudopterogorgia spp. populations, where larger colonies had a high $\left(96 \% \mathrm{y}^{-1}\right)$ and constant survivorship compared to the low $\left(62 \% \mathrm{y}^{-1}\right)$ and variable survivorship in smaller colonies. This resulted in episodic variations in Pseudopterogorgia population size frequencies. Gotelli (1991) noticed high variation in the number of $L$. virgulata recruits on a monthly scale, as well as low juvenile survivorship. Predation does not appear to be a major factor behind L. virgulata juvenile mortality (Patton 1972). Episodic recruitment could potentially explain the significantly different mean ages of the in-situ corals at Memorial Barge and South Ledges. Differential recruitment between the sites could lead to this difference in mean age.

Episodic recruitment can also indicate the instability of the species' environment, as the more variable the environment the more irregular the age structure of a respective population will be (Grigg 1975). One such environmental factor affecting the observed age-frequency in our

Peer) reviewing PDF | (2019:09:41223:1:1:NEW 30 Nov 2019) 
396

397

398

399

400

401

402

403

404

405

406

407

408

409

410

411

412

413

414

415

416

417

418

419

420

421

422

423

424

425

426

427

428

429

430

431

432

433

434

435

study could be storm events. Though their effect on gorgonian communities can be unpredictable and highly variable, large storms can produce strong currents and wave action resulting in the burial, sand scouring, breakage, and detachment of corals (Yoshioka and Yoshioka 1987). Detachment and abrasion were a major cause of mortality in Grigg's (1977) study examining populations of the branching gorgonians Muricea californica and Muricea fruticosa, with colonies able to withstand detachment by strong currents until they reached a threshold height and size. Gotelli (1988) concluded that high sediment concentrations limit recruitment of $L$. virgulata larvae by restricting settlement sites, and that sand was an important source of juvenile mortality due to the burial or damage of young or newly settled individuals. Larger, adult colonies appear to be tolerant of heavy sediment loads, perhaps due to their established holdfast and additional height (Williamson et al. 2011). Storm events could also be the reason why our age frequency and distribution differed from that of Mitchell et al. (1993), whose study population of $L$. virgulata experienced two hurricanes within 8 years of the project. The Memorial Barge site is the shallowest and northern-most of all our sampled sites. Wind records from NOAA Buoy 44009 (Delaware Bay), located $26.4 \mathrm{~km}$ to the northeast, indicate that a major storm in November of 2009 caused wave heights $>8 \mathrm{~m}$ for two days; this event could have removed sea whip colonies and other organisms from the site, opening settlement areas for new recruits, which would explain the age distribution at that site. Hurricane Sandy (Oct 22, 2012) caused wave heights of $7.4 \mathrm{~m}$ for one day; maximum wave heights in 2014-2015 were $<6 \mathrm{~m}$, but in January of 2016, two consecutive days with winds $>20 \mathrm{~m} \cdot \mathrm{s}^{-1}$ and waves $>8.4 \mathrm{~m}$ occurred, which destroyed both the wave height and wind speed sensors.

In addition to storm activity, we speculated as to how variation in depth and water temperature may have led to the different age distribution and frequency found between our study and Mitchell et al. (1993). There are contradictions about how depth, and associated flow velocities, affect gorgonians. Dai and Lin (1993) state that gorgonian corals feed optimally at moderate flow velocities, and Lasker et al. (1983) found that feeding rates of both gorgonian species studied were lower at $29 \mathrm{~m}$ than $17 \mathrm{~m}$, but they could capture food at both. Contrastingly, Sanchez et al. (1997) found greater gorgonian diversity and cover to occur on mid to low relief sections of fore reef terraces, where wave turbulence, flow rate, and turbidity is higher. When looking at temperature, Rossi et al. (2004) found the digestion time of Leptogorgia sarmentosa to increase as temperature decreased, which would lead to slower growth rates in colder temperatures. However, Previati et al. (2010) found the respiration rate of four gorgonian species to decrease at temperatures higher than $18-20^{\circ} \mathrm{C}$, indicating a reduction of metabolic activity at higher temperatures. At a sustained 3 day temperature of $25^{\circ} \mathrm{C}$, the three azooxanthellate corals exhibited the first signs of necrosis. With the coastal waters of the Gulf of Mexico reaching average temperatures higher than this in the summer months, the survival of L. virgulata colonies in Mitchell et al. (1993) could have been negatively impacted, resulting in the different age frequency and distribution observed.

Another factor preventing regular recruitment in the population studied by Grigg (1977) was the lack of available hard substrata for settlement, a determining factor of recruitment for 
436 many gorgonians (Kenzie 1973). Therefore, recruitment may be regulated by space limitation in 437 habitats where hard substrata is completely occupied, or covered in a soft sediment layer. Coral 438 larvae that do manage to settle may then have to compete with other sessile organisms, and risk 439 mortality by overgrowth (Gomez et al. 2014). On our study sites, the hard substrata of the 440 artificial reef were often covered in beds of mussels, sponges, and the encrusting star coral 441 Astrangia poculata, as well as an occasional layer of fine sediment. Thus new coral recruits may 442 find stiff competition for available substrata on these sites crowded with other organisms. Years 443 of high L. virgulata recruitment may result after a removal or mortality event affects established 444 sessile organisms or sediment layers, clearing space for coral settlement. This was the case in 445 Grigg's (1977) study, where occasional periods of exposed hard bottom due to shifting sediments resulted in fluctuating recruitment of Muricea. Large year classes resulted from years of heavy

448 (Memorial Barge) in 2016, but when that site was revisited in 2017, the mussels were scarce and 449

450

451

452

453

454

455

456

457

458

459

460

461

462

463

464

465

466

467

468

469

470

471

472

473

474

475

476 much smaller; by 2019, the site was again covered with a deep layer of small mussels. This suggests that mussels may have been removed by winter storms between visits, and replaced by new recruits, which could have direct impacts on coral recruitment. This conclusion is supported by wind data. Unfortunately, NOAA Data Buoy 44009 was not repaired until January 2017, so there are no wind or wave height data during the fall of 2016, although records from Buoy OCIM2 (Ocean City Inlet) show winds reaching $17.2 \mathrm{~m} \cdot \mathrm{s}^{-1}$ on October 9, 2016, one week after we sampled the site. Wave heights associated with winds $>17.5 \mathrm{~m}$ at NDBC 44009 were typically $>4 \mathrm{~m}$.

\section{Growth}

The generated age-length keys show the overall pattern of coral size increasing with age. Anomalies to the trend found in the observed age-length key could be due to variable ages and/or small sample sizes in some length intervals, which are common issues within these keys. The multinomial logistic regression applied in the smoothed age-length key addresses those issues and better shows the trend of increased age with total coral length. Gotelli (1991) also found a correlation between L. virgulata colony size and age, with considerable variation in the size of older individuals. Variation of growth rate between colonies, and the subsequent variation in length for colonies of similar ages, may be due to persistent intrinsic differences, minor differences in food supply related to position on the reef, or other differences in the microhabitat (Grigg 1974). This variation could also be explained by the potential net negative growth of older colonies whose branches have experienced damage or tip removal, reducing their total length (personal observation; Grigg 1974; Mistri and Ceccherelli 1994; Rossi et al. 2011; Cupido et al. 2012).

For organisms with indeterminate growth and variation of size within an age class, it has been recommended to use population dynamic models based not only on age, but on simultaneous analyses of size and age (Kirkpatrick 1984; Hughes 1984; Hughes and Connell 1987). We accomplished this using a von Bertalanffy growth model illustrating L. virgulata size at age. According to this growth function, L. virgulata reaches maximum individual length at 
477 approximately 20 years of age. Gorgonian corals tend to grow toward a theoretically high size 478 asymptote, with their size and lifespan then being limited ecologically (Grigg 1974; Mistri and 479 Ceccherelli 1993, 1994; Goffredo and Lasker 2006; Munari et al. 2013) - a trend that appears to 480 apply to L. virgulata. Other constraints on size may be physical, like the biomechanics of a coral

481

482

483

484

485

486

487

488

489

490

491

492

493

494

495

496

497

498

499

500

501

502

503

504

505

506

507

508

509

510

511

512

513

514

515

516 skeleton with a highly branched structure (Chadwick-Furman et al. 2000). Mitchell et al. (1993) produced a growth function for $L$. virgulata using a Walford plot, where a $\mathrm{K}$ parameter equal to $0.094 \mathrm{y}^{-1}$ can be derived from the slope. This is a lower rate of approach compared to our $\mathrm{K}$ value of $0.14 \mathrm{y}^{-1}$, suggesting the sea whips in our study approach $\mathrm{L}_{\infty}$ at a slightly faster rate.

With no corals over the age of 15 , and $50 \%$ in the range of 6 to 8 y, our study sites are dominated by middle-age colonies. Our curve seems to be slightly below the rapid, two-year initial growth rate of $L$. virgulata which Adams (1980) observed, where age-2 corals averaged 14 $\mathrm{cm}$ in height. However, that study mimicked water conditions of the Gulf of Mexico, so the warmer temperatures could have potentially increased $L$. virgulata growth rate in comparison to our study. This difference could also be due to sample size limitation, as we found only one coral aged $2 \mathrm{y}(8 \mathrm{~cm})$, and no corals younger than that. This colony displayed a growth rate of $4 \mathrm{~cm}$ per year, which is lower than the $7 \mathrm{~cm}$ per year calculated by Adams (1980) for age- 2 colonies. In general, younger corals were scarce in our samples, with only fourteen corals under 6 y out of the 102 collected. This could have affected the $t_{0}$ model parameter, age at length $0 \mathrm{~cm}$. Additionally, only $22.5 \%$ of the corals collected were over $8 \mathrm{y}$, which could potentially alter the rate of approach $(\mathrm{K})$ to $\mathrm{L}_{\infty}$.

The presence of mostly middle-age colonies at our study sites implies that adult survivorship is high for these populations. In Gotelli's (1991) study of $L$. virgulata, the population growth rate (growth rate measured as the proportion of colonies in size class $i$ that grew to size class $i+1$ in the next month) was close to 0.0 . Thus, it was clear that adult survivorship was more important to population growth than either recruitment or fecundity. One reason for this could be fluctuating juvenile mortality (Gotelli 1988; Gotelli 1991; Yoshioka 1994). Therefore, the presence of many middle-age adults at our sites could be considered beneficial in terms of maintaining overall population structure and growth. However, Gotelli (1991) did mention that recruitment was important in terms of stabilizing the population growth of $L$. virgulata.

In the Delmarva region of the MAB there is evidence of threats to adult survivorship, and subsequently the population stability of $L$. virgulata populations. Schweitzer et al. (2018) observed commercial fishing activities at 3 sites in this region, and found that $50 \%$ of the commercial fishing traps observed came into contact with benthic epifauna, including sea whips, upon retrieval. As a result, sea whips could be damaged or experience breakage, reducing their overall structural complexity and density. Our study sites are not commercially fished, however they are fished recreationally. Observed damage to sea whips at these sites includes fishing lines entangled in biotic overgrowth attached to the corals, lines restricting coral branches, lines cutting into coral tissue, and damaged and stripped tissue in general. Future work is needed to examine to what degree fishing damages $L$. virgulata or affects its survival; however, numerous 
517 studies have highlighted the negative impacts fishing can have on cold-water corals (Van Dolah 518 et al. 1987; Fosså et al. 2002; Freiwald et al. 2004; Roberts et al. 2006; Watling et al. 2011).

519

520

521

522

523

524

525

526

527

528

529

530

531

532

533

534

535

536

537

538

539

540

541

542

543

544

545

546

547

548

549

550

551

552

553

554

555

\section{Conclusions}

This study currently represents the only measure of colony complexity, age, and growth for L. virgulata on artificial reefs in the mid-Atlantic region, and will be a useful reference to study changes over time and/or long-term population trends. However, the number of sites observed and corals analyzed may represent a fraction of the total number in this region (Office of Coastal Survey 2019). Therefore, more research into the location and biology of L. virgulata in this region is necessary to better verify the coral characteristics presented in our study. While ageing corals via growth ring counts may be a more accurate technique, the growth function generated in our study could be used in the field to estimate age-frequency without removal of specimens. Additionally, measuring in-situ changes in total coral length via tagging studies would give more insight into growth rates of L. virgulata. They could also be used to improve our understanding of the capacity for, and rates of recovery of sea whip populations after damage or removal by either human or natural disturbance. The evidence for episodic recruitment of $L$. virgulata shown in this study suggests that they do not recruit on a regular annual basis, and good recruitment years may only occur at intervals of a decade or longer. Thus, any corals that are damaged or removed due to disturbance by human or natural events may require decades to recover. Changes in fishing patterns, storm events, or climate change may exacerbate or change this pattern. Presently, the most conspicuous human disturbances to L. virgulata in the midAtlantic result from trap and hook and line fishing. However, the planned development of offshore wind-power energy areas (Maryland Energy Administration 2019) may also impact coral populations in the future. In addition, our study only looked at recreationally fished sites because most natural bottom sites in our area (and those targeted by commercial fishers) were at depths $>25 \mathrm{~m}$, beyond the range of air-based scuba. Studies using cameras and ROVs (Schweitzer et al. 2018) show that L. virgulata is common on natural reefs targeted by commercial fishing at depths of 20-33 m, and visual observations do not indicate any difference between colonies at those sites and the ones we studied. Therefore, it would be beneficial for future studies to examine sea whips at commercially fished sites in order to compare them.

Regarding natural disturbance, storm events are most likely the biggest source of damage, and the frequency and intensity of storm events should be considered for long-term modeling, management, and habitat protection. Finally, because our study sites only included artificial reef sites, it would be valuable to examine sea whips on natural hard-bottom to determine if there are any differences between corals on artificial and natural reefs. Once the information regarding population distribution, biology, and trends in these waters have been more thoroughly documented, the development of population models for coral communities would be beneficial.

\section{Acknowledgements}


556 The authors would like to thank J. Kogon and the OC Dive Boat crew, as well as J. Dykman, L. 557 Burke, M. Hutchins, and D. Cullen.

558

559

560

561

562

563

564

565

566

567

568

569

570

571

572

573

574

575

576

577

578

579

580

581

582

583

584

585

586

587

588

589

590

591

592

593

\section{References}

Able, K.W., and M.P. Fahay. 1998. The first year in the life of estuarine fishes in the Middle Atlantic Bight. Rutgers University Press, New Brunswick, New Jersey. https://doi.org/10.2307/1447411.

Adams, R.O. 1980. Investigations of color, morphology and development of the sea whip Leptogorgia virgulata (Lamarck) (Cnidaria: Octocorallia: Gorgonacea). Dissertation. Florida State University, Tallahassee, Florida, USA.

Baillon, S., J-F Hamel, V.E. Wareham, and A. Mercier. 2012. Deep cold-water corals as nurseries for fish larvae. Frontiers in Ecology and the Environment 10(7):351-356. https://doi.org/10.1890/120022.

Baty, F., C. Ritz, S. Charles, M. Brutsche, J-P Flandrois, and M-L Delignette-Muller. 2015. A toolbox for nonlinear regression in R: The package nlstools. Journal of Statistical Software 66(5):1-21. Available at http://www.jstatsoft.org/v66/i05/.

Bayer, F.M. 1961. The shallow-water octocorallia of the West Indian Region: A manual for marine biologists. Studies of the Fauna Curacao and Other Caribbean Islands 12: 1-373.

Beverton, R.J.H., and S.J. Holt. 1957. On the dynamics of exploited fish populations. Fishery Investigations. H.M.S.O., London, England.

Birkeland, C. 1974. The effect of wave action on the population dynamics of Gorgonia ventalina Linnaeus. Studies in Tropical Oceanography 12:115-126.

Brazeau, D.A., and H.R. Lasker. 1988. Inter- and intraspecific variation in gorgonian colony morphology: quantifying branching patterns in arborescent animals. Coral Reefs 7:139143. https://doi.org/10.1016/B978-0-12-811963-1.00001-9.

Capezutto, F., L. Sion, F. Ancona, R. Carlucci, A. Carluccio, L. Cornacchia, P. Maiorano, P. Ricci, A. Tursi, and G. D’Onghia. 2018. Cold-water coral habitats and canyons as essential fish habitats in the southern Adriatic and northern Ionian Sea (central Mediterranean). Ecological Questions 29:9-23. https://doi.org/10.12775/EQ.2018.019

Chadwick-Furman, N.E., S. Goffredo, and Y. Loya. 2000. Growth and population dynamic model of the reef coral Fungia granulosa Kluzinger, 1879 at Eilat, northern Red Sea. Journal of Experimental Marine Biology and Ecology 249:199-218. https://doi.org/10.1016/S0022-0981(00)00204-5.

Clare, A.S., D. Rittschof, D.J. Gerhart, I.R. Hooper, and J. Bonaventura. 1999. Antisettlement and narcotic action of analogues of diterpene marine natural product antifoulants from octocorals. Marine Biotechnology 1:427-436.

Coull B.C., and J.B.J. Wells. 1983. Refuges from fish predation: experiments with phytal meiofauna from the New Zealand rocky intertidal. Ecology 64:1599-1609. 
594 Cullen, D., and B. G. Stevens. 2017. Use of an underwater video system to record observations

595

596

597

598

599

600

601

602

603

604

605

606

607

608

609

610

611

612

613

614

615

616

617

618

619

620

621

622

623

624

625

626

627

628

629

630

631

632 of black sea bass (Centropristis striata) in waters off the coast of Maryland. Fishery Bulletin 115:408-418. https://doi.org/10.1007/s12562-017-1116-y.

Cupido, R., S. Cocito, V. Manno, S. Ferrando, A. Peirano, M. Iannelli, L. Bramanti, and G. Santangelo. 2012. Sexual structure of a highly reproductive, recovering gorgonian population: quantifying reproductive output. Marine Ecology Progress Series 469:25-36.

Dai, C-F, and M-C Lin. 1993. The effects of flow on feeding of three gorgonians from southern Taiwan. Journal of Experimental Marine Biology and Ecology 173:57-69. https://doi.org/10.1016/0022-0981(93)90207-5.

Devictor, S.T. and S.L. Morton. 2010. Identification guide to the shallow water (0-200 m) octocorals of the South Atlantic Bight. Zootaxa 2599:1-62.

Diaz, R. J., G. R. Cutter, and K. W. Able. 2003. The importance of physical and biogenic structure to juvenile fishes on the shallow inner continental shelf. Estuaries 36:12-20. https://doi.org/10.1007/BF02691689.

Fabrizio, M.C., J.P. Pessutti, and J.P Manderson. 2013. Habitat associations and dispersal of black sea bass from a Mid-Atlantic Bight reef. Marine Ecological Progress Series 482:241-253. https://doi.org/10.3354/meps10302.

Foley, N.S., V. Kahui, C.W. Armstrong, and T.M. Van Rensburg. 2010. Estimating linkages between redfish and cold water coral on the Norwegian coast. Marine Resource Economics 25:105-20. https://doi.org/10.5950/0738-1360-25.1.105.

Fosså, J.H., P.B. Mortensen, and D.M. Furevik. 2002. The deep-water coral Lophelia pertusa in Norwegian waters: distribution and fishery impacts. Hydrobiologia 471:1-12.

Freiwald, A., J.H. Fosså, A. Grehan, T. Koslow, and J.M. Roberts. 2004. Cold-water coral reefs: out of sight - no longer out of mind. UNEP-WCMC Biodiversity Series, 22. https://doi.org/10.5962/bhl.title.45025

Gerhart, D.J., D. Rittschof, and S.W. Mayo. 1988. Chemical ecology and the search for marine antifoulants. Studies of a predator-prey symbiosis. Journal of Chemical Ecology 14:1905-1918.

Goffredo, S., G. Mattioli, and F. Zaccanti. 2004. Growth and population dynamics model of the Mediterranean solitary coral Balanophyllia europeae (Scleractinia, Dendrophylliidae). Coral Reefs 23:433-443. https://doi.org/10.1007/s00338-004-0395-9.

Goffredo, S. and H.R. Lasker. 2006. Modular growth of a gorgonian coral can generate predictable patterns of colony growth. Journal of Experimental Marine Biology and Ecology 336:221-229. https://doi.org/10.1016/j.jembe.2006.05.012.

Gomez, G.C., Guzman, M.H., Gonzalez, A. and Odalisca, B. 2014. Survival, growth, and recruitment of octocoral species (Coelenterata: Octocorallia) in Coiba National Park, Pacific Panama. Bulletin of Marine Science 90:623-650.

Gotelli, N.J. 1988. Determinants of recruitment, juvenile growth, and spatial distribution of a shallow-water gorgonian. Ecology 69:157-66. https://doi.org/10.2307/1943170 
633 Gotelli, N. J. 1991. Demographic models for Leptogorgia virgulata, a shallow-water gorgonian.

634

635

636

637

638

639

640

641

642

643

644

645

646

647

648

649

650

651

652

653

654

655

656

657

658

659

660

661

662

663

664

665

666

667

668

669

670

671 Ecology 72(2):457-467. https://doi.org/10.2307/2937187.

Grigg, R. W. 1974. Growth rings: annual periodicity in two gorgonian corals. Ecology 55(4):876-881.

Grigg, R.W. 1975. Age structure of a longevous coral: A relative index of habitat suitability and stability. The American Naturalist 109:647-657. https://doi.org/10.1086/283035.

Grigg, R.W. 1977. Population dynamics of two gorgonian corals. Ecology. 58:278-290.

Hereu, B., M. Zabala, C. Linares, and E. Sala. 2005. The effects of predator abundance and habitat structural complexity on survival of juvenile sea urchins. Marine Biology 146:293-299. https://doi.org/10.1007/s00227-004-1439-y.

Hughes, T.P. 1984. Population dynamics based on individual size rather than age: A general model with a reef coral example. The American Naturalist 123:778-795.

Hughes, T.P., and J.H. Connell. 1987. Population dynamics based on size or age? A reef-coral analysis. The American Naturalist 129:818-829.

Jenkins, G.P., H.M.A. May, M.J. Wheatley, and M.G. Holloway. 1997. Comparison of fish assemblages associated with seagrass and adjacent unvegetated habitats of Port Phillip Bay and Corner Inlet, Victoria, Australia, with emphasis on commercial species. Estuarine, Coastal and Shelf Science 44:569-588. https://doi.org/10.1006/ecss.1996.0131.

Kelaher, B. P., and J. C. Castilla. 2005. Habitat characteristics influence macrofaunal communities in coralline turf more than mesoscale upwelling on the coast of northern Chile. Estuarine, Coastal and Shelf Science 63:155-165. https://doi.org/10.1016/j.ecss.2004.10.017.

Kinzie, R. A. 1973. The zonation of West Indian gorgonians. Bulletin of Marine Science 23:93155.

Kirkpatrick, M. 1984. Demographic models based on size, not age, for organisms with indeterminate growth. Ecology 65:1874-1884. https://doi.org/10.2307/1937785.

Lasker, H.R., M.D. Gottfried, and M.A. Coffroth. 1983. Effects of depth on the feeding capabilities of two octocorals. Marine Biology 73:73-78.

Luckhurst, B. E., and K. Luckhurst. 1978. Analysis of the influence of substrate variables on coral reef fish communities. Marine Biology 49:317-323. https://doi.org/10.1007/BF00455026.

MacArthur, R.H., and J.W. MacArthur. 1961. On bird species diversity. Ecology 42:594-598.

Maryland Energy Administration. 2019. Offshore wind energy in Maryland. https://energy.maryland.gov/Pages/Info/renewable/offshorewind.aspx.

Mistri, M. and V.U. Ceccherelli. 1993. Growth of the Mediterranean gorgonian Lophogorgia ceratophyta (L., 1758). P.S.Z.N.I. Marine Ecology 14:329-340.

Mistri, M. and V.U. Ceccherelli. 1994. Growth and secondary production of the Mediterranean gorgonian Paramuricea clavata. Marine Ecology Progress Series 103:291-296. https://doi.org/10.3354/meps 103291. 
672 Mitchell, N.D., M. R. Dardeau, and W.W. Schroeder. 1993. Colony morphology, age structure,

673

674

675

676

677

678

679

680

681

682

683

684

685

686

687

688

689

690

691

692

693

694

695

696

697

698

699

700

701

702

703

704

705

706

707

708

709 and relative growth of two gorgonian corals, Leptogorgia hebes (Verrill) and Leptogorgia virgulata (Lamarck), from the northern Gulf of Mexico. Coral reefs 12(2):65-70. https://doi.org/10.1007/BF00302103.

Mock, S.J. 1971. A classification of channel links in stream networks. Water Resources Research 7:1558-1566. https://doi.org/10.1029/WR007i006p01558.

Munari, C., G. Serafin, and M. Mistri. 2013. Structure, growth and secondary production of two Tyrrhenian populations of the white gorgonian Eunicella singularis (Esper 1791). Estuarine Coastal and Shelf Science 119:162-166. https://doi.org/10.1016/j.ecss.2013.01.007.

Office of Coast Survey. 2019. Wrecks and obstructions database. https://nauticalcharts.noaa.gov/data/wrecks-and-obstructions.html

Ogle, D. H. 2016. Introductory fisheries analyses with R. CRC Press.

Ogle, D.H. 2018. FSA: Fisheries stock analysis. R package version 0.8.20. Available at https://cran.r-project.org/web/packages/FSA/FSA.pdf

Packer, D.B., M.S. Nizinski, S.D. Cairns, and T.F. Hourigan. 2017. Deep-sea coral taxa in the U.S. northeast region: Depth and geographical distribution. Available at https://repository.si.edu/handle/10088/34997

Patton, W.K. 1972. Studies on the animal symbionts of the gorgonian coral, Leptogorgia virgulata (Lamarck). Bulletin of Marine Science 22:419-431.

Pianka E.R. 1978. Evolutionary ecology ( $5^{\text {th }}$ ed.). HarperCollins, New York, USA.

Previati, M., A. Scinto, C. Cerrano, and R. Osinga. 2010. Oxygen consumption in Mediterranean octocorals under different temperatures. Journal of Experimental Marine Biology and Ecology 390:39-48.

R Core Team. 2017. R: A language and environment for statistical computing. R Foundation for Statistical Computing. Vienna, Austria. Available at https:/www.R-project.org/

Roberts, J.M., A.J. Wheeler, and A. Freiwald. 2006. Reefs of the deep: The biology and geology of cold-water coral ecosystems. Science 312:543-547.

Ross, S.W., M. Rhode, S.T. Viada, and R. Mather. 2016. Fish species associated with shipwreck and natural hard-bottom habitats from the middle to outer continental shelf of the Middle Atlantic Bight near Norfolk Canyon. Fishery Bulletin 114:45-57. https://doi.org/10.7755/FB.114.1.4.

Rossi, S., M. Ribes, R. Coma, and J-M Gili. 2004. Temporal variability in in zooplankton prey capture rate of the passive suspension feeder Leptogorgia sarmentosa (Cnidaria: Octocorallia), a case study. Marine Biology 144:89-99.

Rossi, S., J-M Gili, and X. Garrofé. 2011. Net negative growth detected in population of Leptogorgia sarmentosa: quantifying the biomass loss in a benthic soft bottom-gravel gorgonian. Marine Biology 158(7):1631-1643. 
710 Ruppert, E.E. and R.S. Fox. 1988. Seashore animals of the southeast. A guide to common

711

712

713

714

715

716

717

718

719

720

721

722

723

724

725

726

727

728

729

730

731

732

733

734

735

736

737

738

739

740

741

742

743

744

745

746

747

748 shallow-water invertebrates of the Southeastern Atlantic Coast. University of South Carolina Press, Columbia, South Carolina.

Sánchez, J.A., J.M. Díaz, and S. Zea. 1997. Gorgonian communities in two contrasting environments on oeanic atolls of the southwestern Caribbean. Bulletin of Marine Science 61(2):453-465.

Scharf, F.S., J.P. Manderson, and M.C. Fabrizio. 2006. The effects of seafloor habitat complexity on survival of juvenile fishes: species-specific interactions with structural refuge. Journal of Experimental Marine Biology and Ecology 335:167-176. https://doi.org/10.1016/j.jembe.2006.03.018.

Schweitzer, C.C., R.N. Lipcius, and B.G. Stevens. 2018. Impacts of a multi-trap line on benthic habitat containing emergent epifauna within the Mid-Atlantic Bight. ICES Journal of Marine Science 75(6):2202-2212. https://doi.org/10.1093/icesjms/fsy109.

Schweitzer C.C., and B.G Stevens. 2019. The relationship between fish abundance and benthic community structure on artificial reefs in the Mid-Atlantic Bight, and the importance of sea whip corals Leptogorgia virgulata. PeerJ 7:e7277. https://doi.org/10.7717/peerj.7277

Sedberry, G. R., and R. F. Van Dolah. 1984. Demersal fish assemblages associated with hardbottom habitat in the South Atlantic Bight of the U.S.A. Environmental Biology of Fishes 11:241-258. https://doi.org/10.1007/BF00001372.

Standing, J.D., I.R. Hooper, and J.D. Costlow. 1984. Inhibition and induction of barnacle settlement by natural products present in octocorals. Journal of Chemical Ecology 10: 823-834. https://doi.org/10.1007/BF00987966.

Steimle, F.W., and W. Figley. 1996. The importance of artificial reef epifauna to black sea bass diets in the Middle Atlantic Bight. North American Journal of Fisheries Management 16(2):433-439. https://doi.org/10.1577/1548-8675(1996)016<0433:tioare >2.3.co;2.

Steimle, F.W., and C. Zetlin. 2000. Reef habitats in the Middle Atlantic Bight: Abundance, distribution, associated biological communities, and fishery resource use. Marine Fisheries Review 62(2):24-42.

Strahler, A.N. 1952. Hypsometric (area-altitude) analysis of erosional topography. Bulletin of the Geological Society of America 63:1117-1142. https://doi.org/10.1130/0016$7606(1952) 63$.

Targett, N.M., S.S. Bishop, O.J. McConnell, and J.A. Yoder. 1983. Antifouling agents against the benthic marine diatom, Navicula salinicola. Homarine from the gorgonians Leptogorgia virgulata and L. setacea and analogs. Journal of Chemical Ecology 9:817829. https://doi.org/10.1007/BF00987807.

Van Dolah, R.F., P.H. Wendt, and N. Nicholson. 1987. Effects of a research trawl on a hardbottom assemblage of sponges and corals. Fisheries Research 5:39-54.

Venables, W. N. and B.D. Ripley. 2002. Modern applied statistics with S. Fourth Edition. Springer, New York. 
749

750

751

752

753

754

755

756

757

758

759

760

761

762

763

764

765

766

767

768

769

770

Watling, L., S.C. France, E. Pante, and A. Simpson. 2011. Advances in marine biology (Vol. 60, pp. 44-122). Academic Press, Cambridge, MA, USA. https://doi.org/10.1192/bjp.112.483.211-a.

West, J.M., C.D. Harvell, and A.M. Walls. 1993. Morphological plasticity in a gorgonian coral (Briareum asbestinum) over a depth cline. Marine Ecology Progress Series 94:61-69. https://doi.org/10.3354/meps094061.

Wickham, H., R. François, L. Henry, and K. Müller. 2018. dplyr: A grammar of data manipulation. R package version 0.7.6. Available at https://CRAN.Rproject.org $/$ package $=$ dplyr.

Wicksten, M. K., and C. Cox. 2011. Invertebrates associated with gorgonians in the northern Gulf of Mexico. Marine Biodiversity Records 4:e79. https://doi.org/10.1017/S1755267211000741.

Williamson, E. A., K.B. Strychar, K. Withers, and B. Sterba-Boatwright. 2011. Effects of salinity and sedimentation on the gorgonian coral, Leptogorgia virgulata (Lamarck 1815). Jounral of Experimental Marine Biology and Ecology 409: 331-338.

https://doi.org/10.1016/j.jembe.2011.09.014

Yoshioka, P. M. and B. B. Yoshioka. 1987. Variable effects of hurricane David on the shallow water gorgonians of Puerto Rico. Bulletin of Marine Science 40:132-144.

Yoshioka, P.M. 1994. Size-specific life history pattern of shallow-water gorgonian. Journal of Experimental Marine Biology and Ecology 184:111-122. 
Figure 1

Map of the four artificial reef study sites offshore of Ocean City, MD, where corals were collected.

Includes: Memorial Barge, South Ledges, Sussex Wreck, and Boom Wreck. 


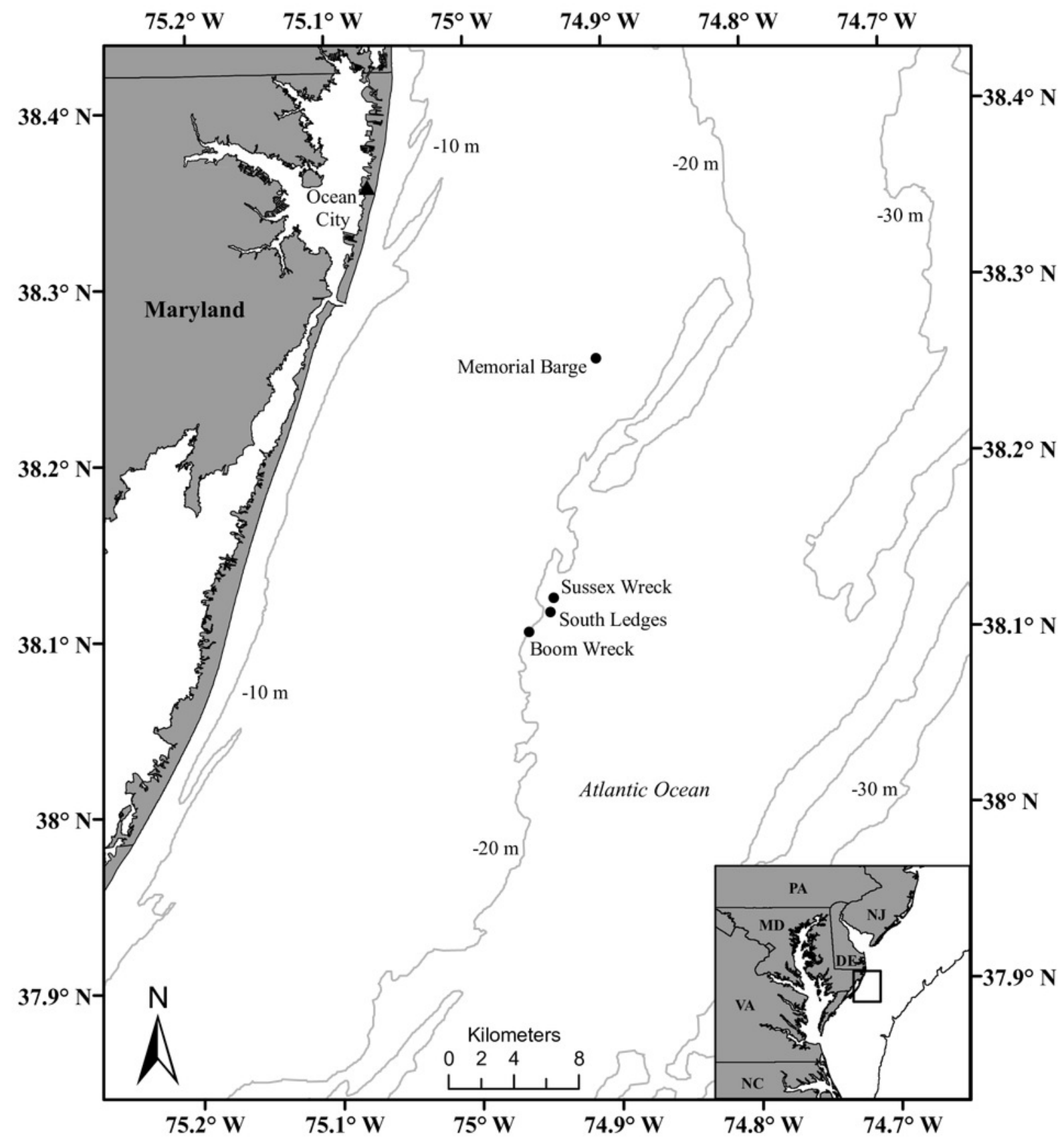


Figure 2

Photo of Leptogorgia virgulata (A), and an example of a simplified branching pattern (B).

The branching pattern exhibits first $\left(1^{\circ}\right)$, second $\left(2^{\circ}\right)$, and third $\left(3^{\circ}\right)$ order branches, as well as their tributary (T) or source (S) status. Adapted from Brazeau and Lasker (1988).

A

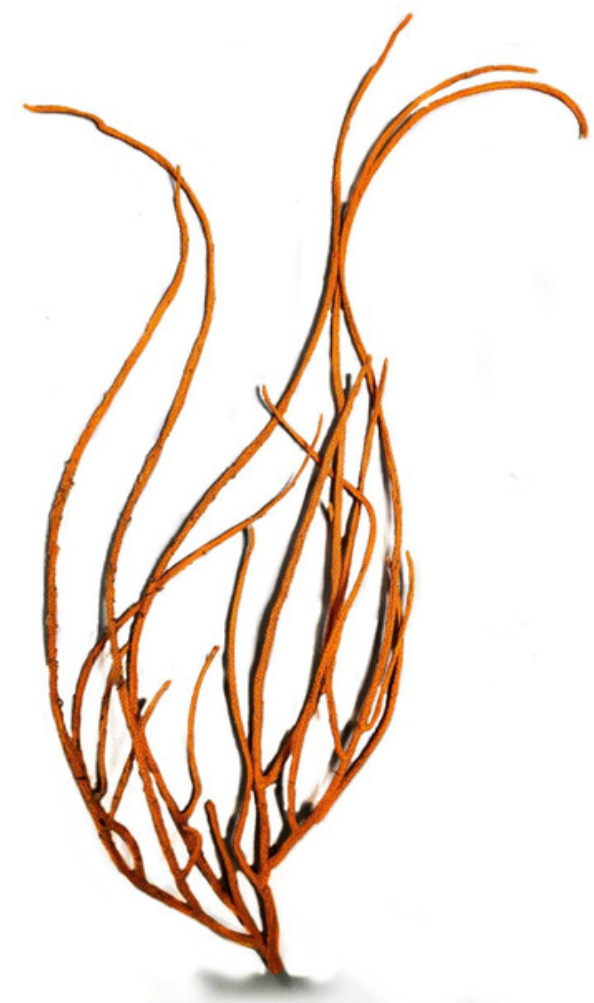

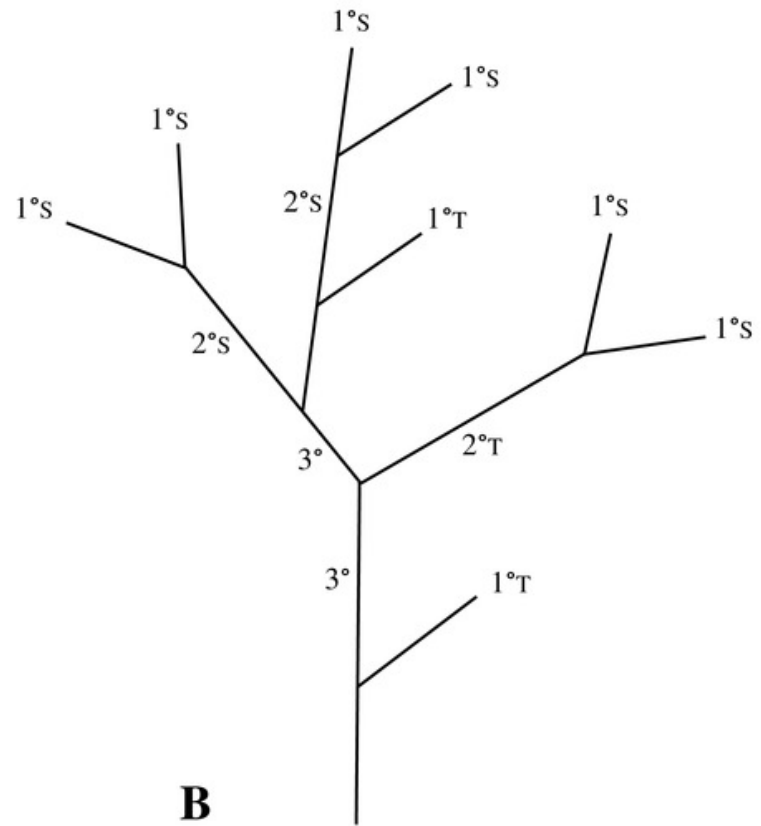




\section{Figure 3}

Growth rings in a basal cross section from a Leptogorgia virgulata colony under a compound microscope.

Growth rings are denoted by the dots, and this colony was estimated to be 9 years old. This cross section is about $3 \mathrm{~mm}$ in diameter.

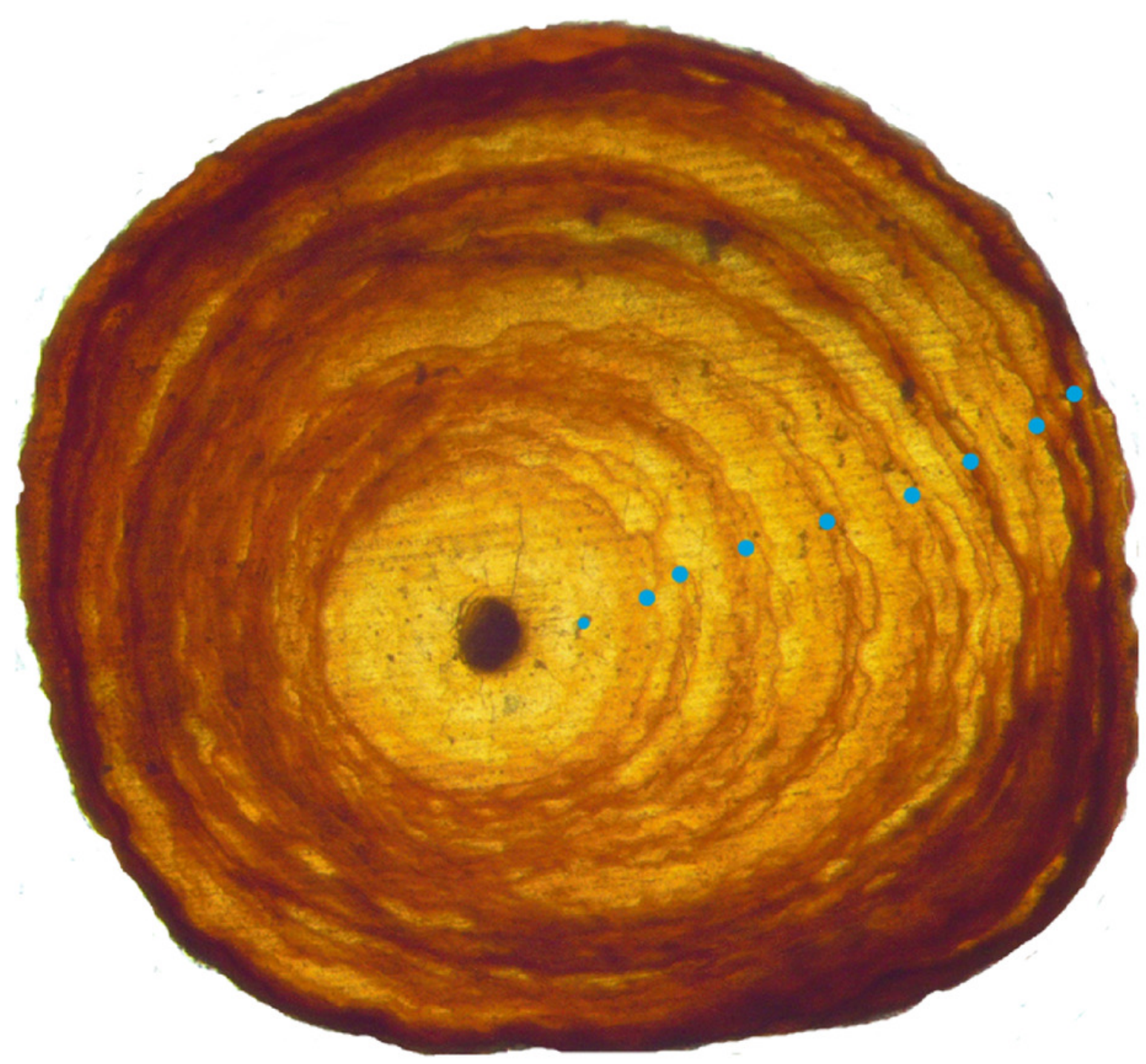


Figure 4

Length frequency of (A) collected and (B) in-situ measured Leptogorgia virgulata colonies.

All four study sites are represented. A, $N=102 ; \mathrm{B}, N=119$. 


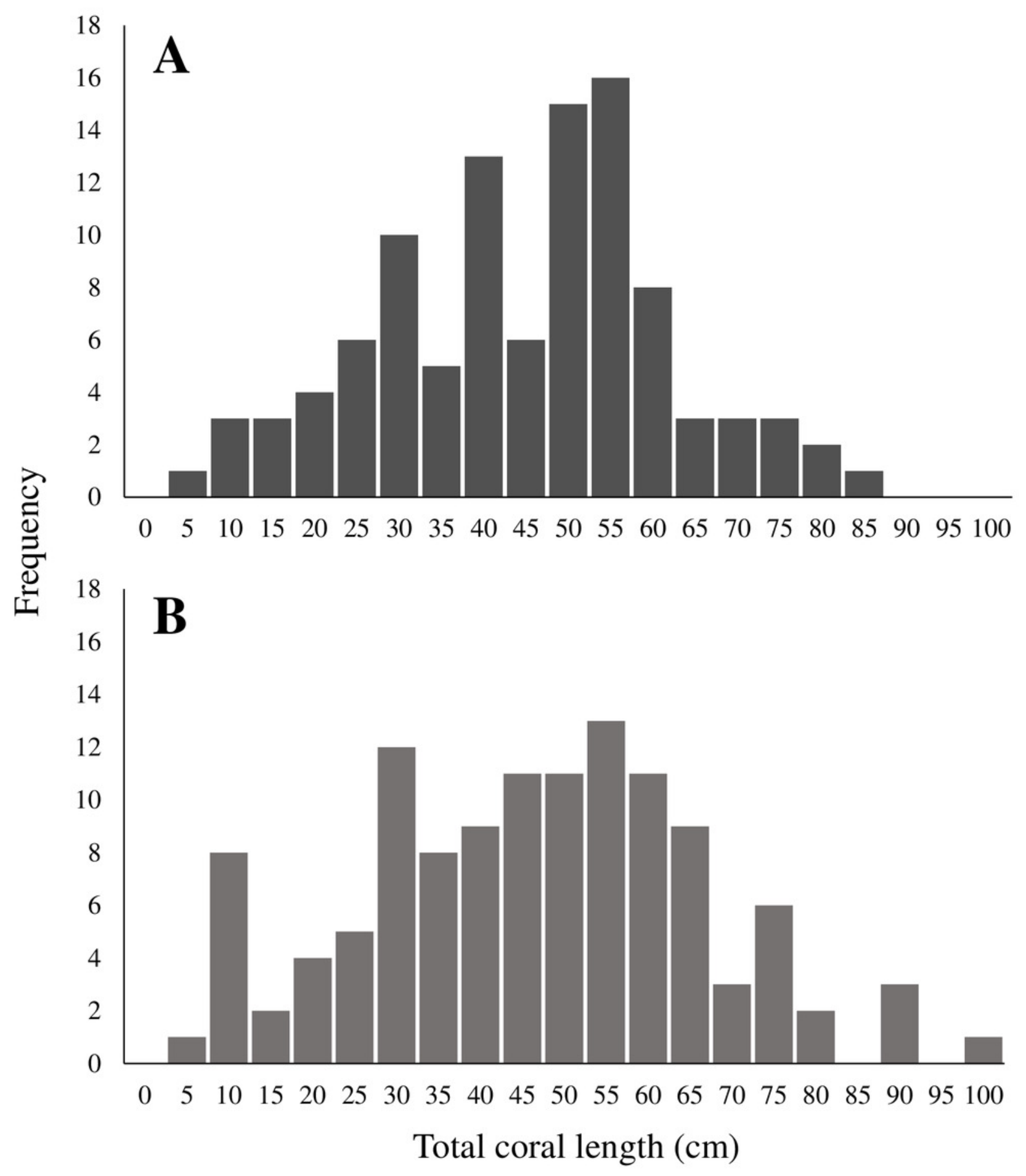


Figure 5

Length frequency of collected and in-situ Leptogorgia virgulata colonies at each study site.

Four study sites: $(A, E)$ Memorial Barge, $(B, F)$ South Ledges, $(C, G)$ Sussex Wreck, and $(D, H)$ Boom Wreck. $N=24,26,29$, and 23 respectively for collected corals, and $N=29,28,31$, and 31 respectively for in-situ corals. 
Collected

A

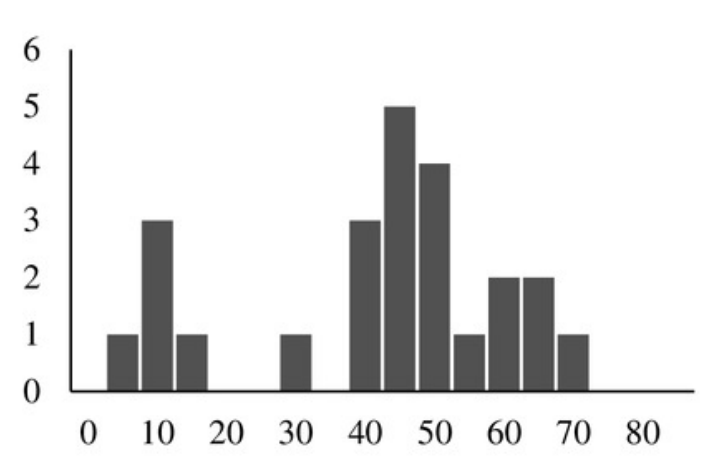

B

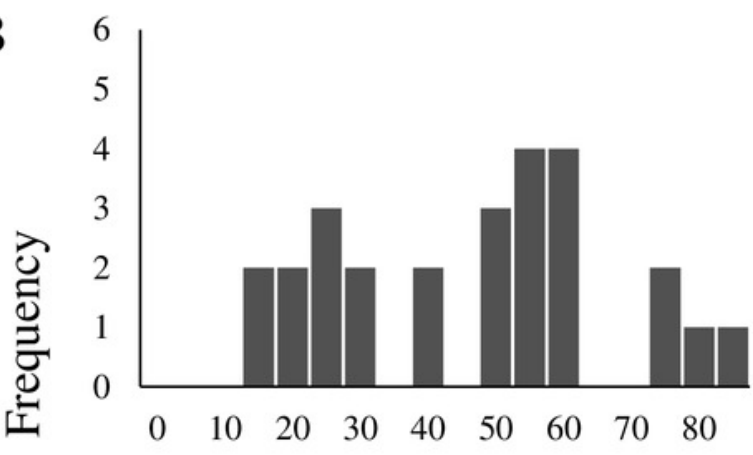

C

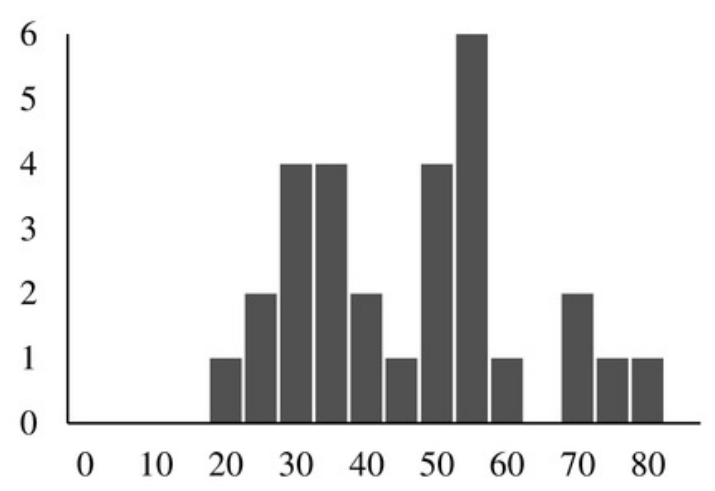

D

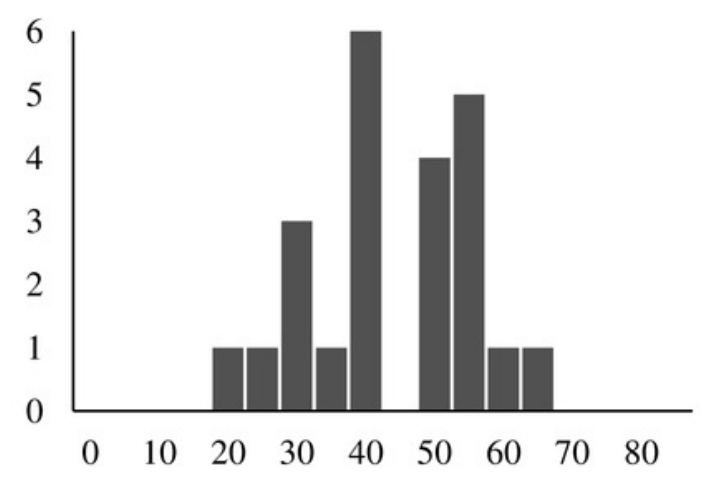

In-Situ
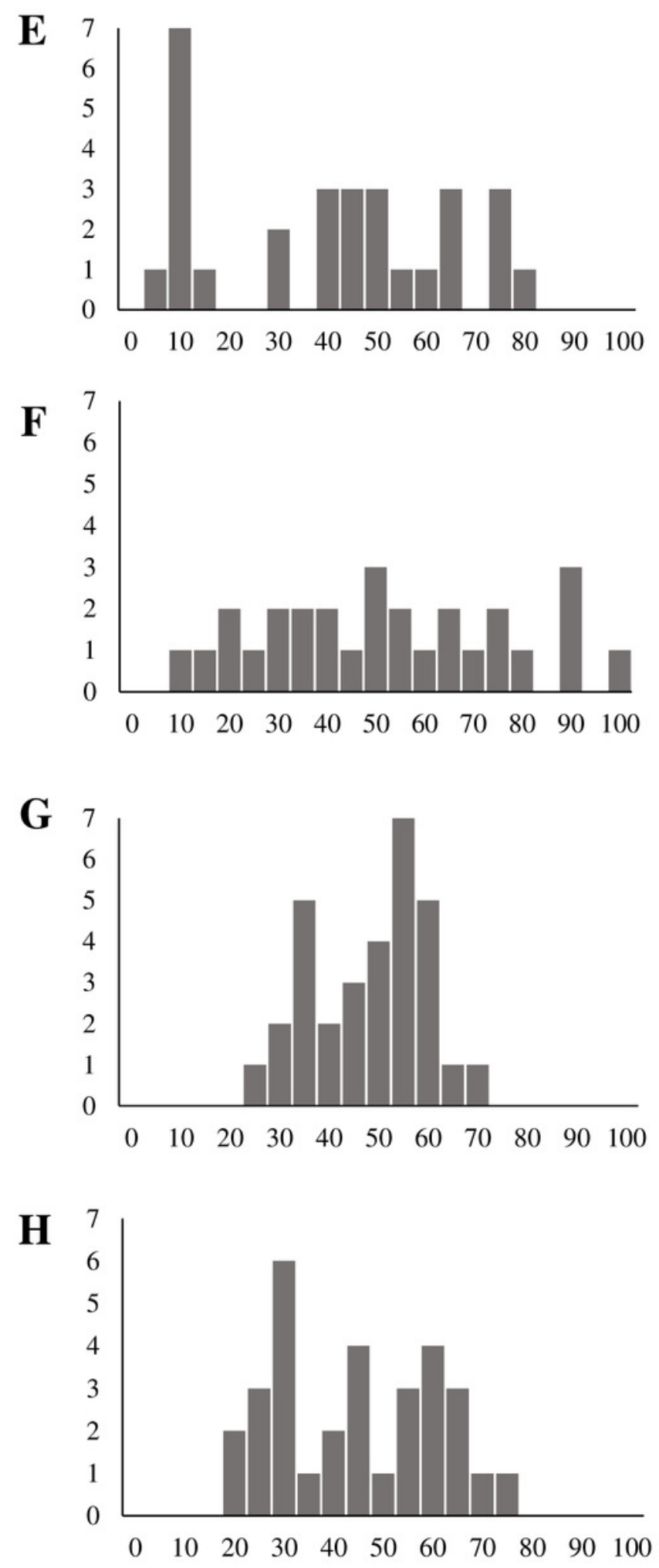

Total coral length $(\mathrm{cm})$ 
Figure 6

Age frequency of (A) collected and (B) in-situ Leptogorgia virgulata colonies.

All four sites are represented. A, N=102; B, N = 119 . 


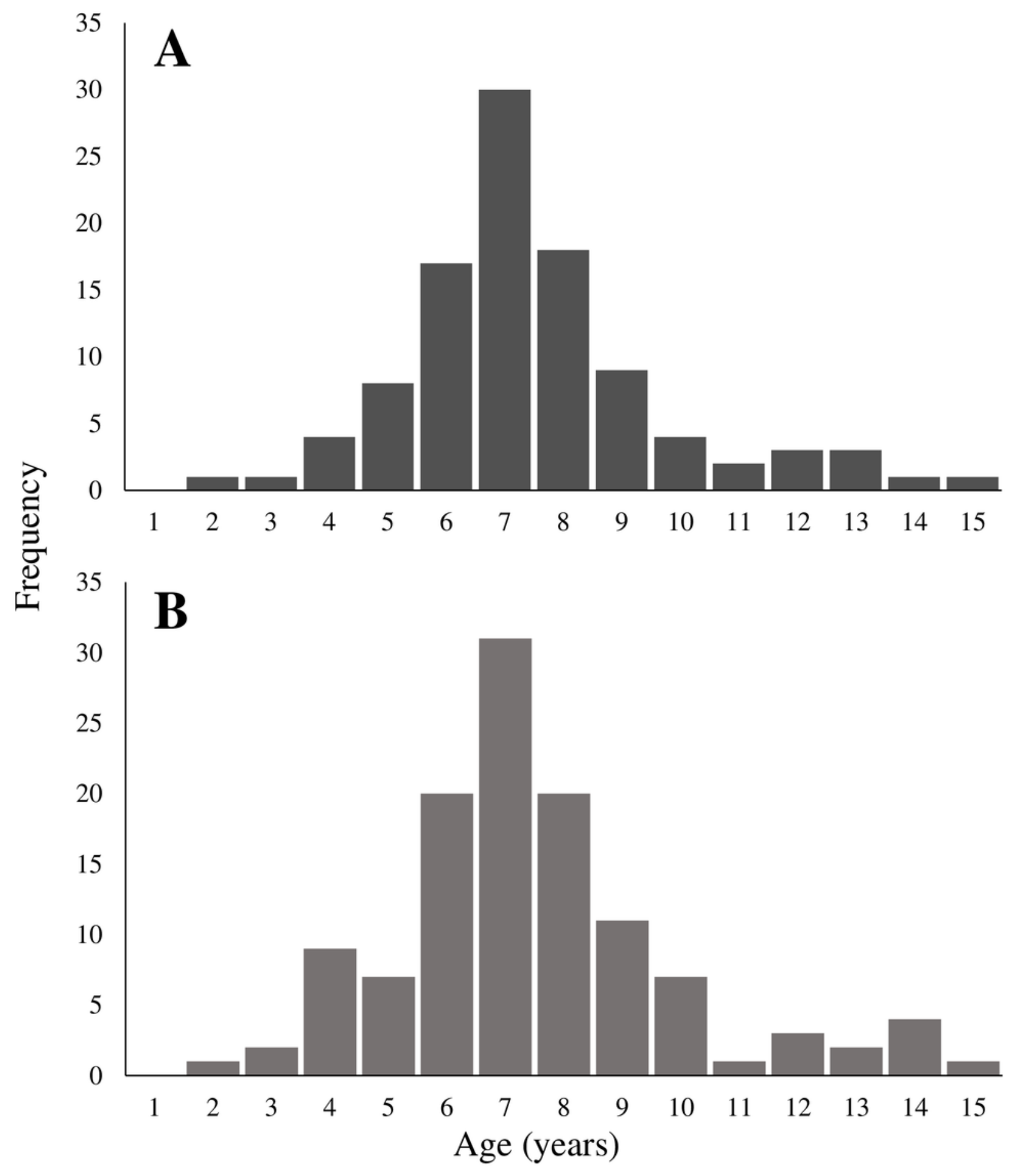


Figure 7

Age frequency of collected and in-situ Leptogorgia virgulata colonies at each study site.

Four study sites: $(A, E)$ Memorial Barge, $(B, F)$ South Ledges, $(C, G)$ Sussex Wreck, and $(D, H)$

Boom Wreck. $N=24,26,29$, and 23 respectively for collected corals, and $N=29,28,31$, and 31 respectively for in-situ corals. 
Collected
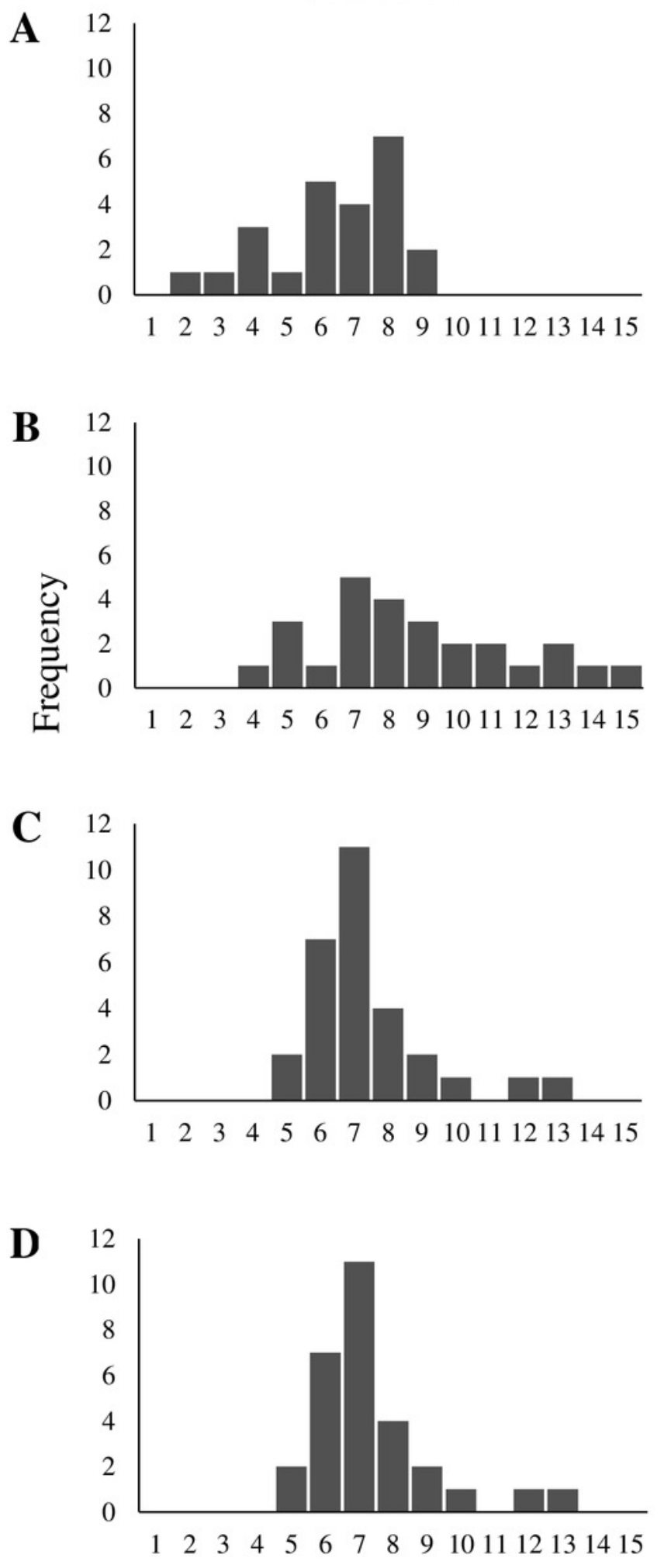

In-Situ
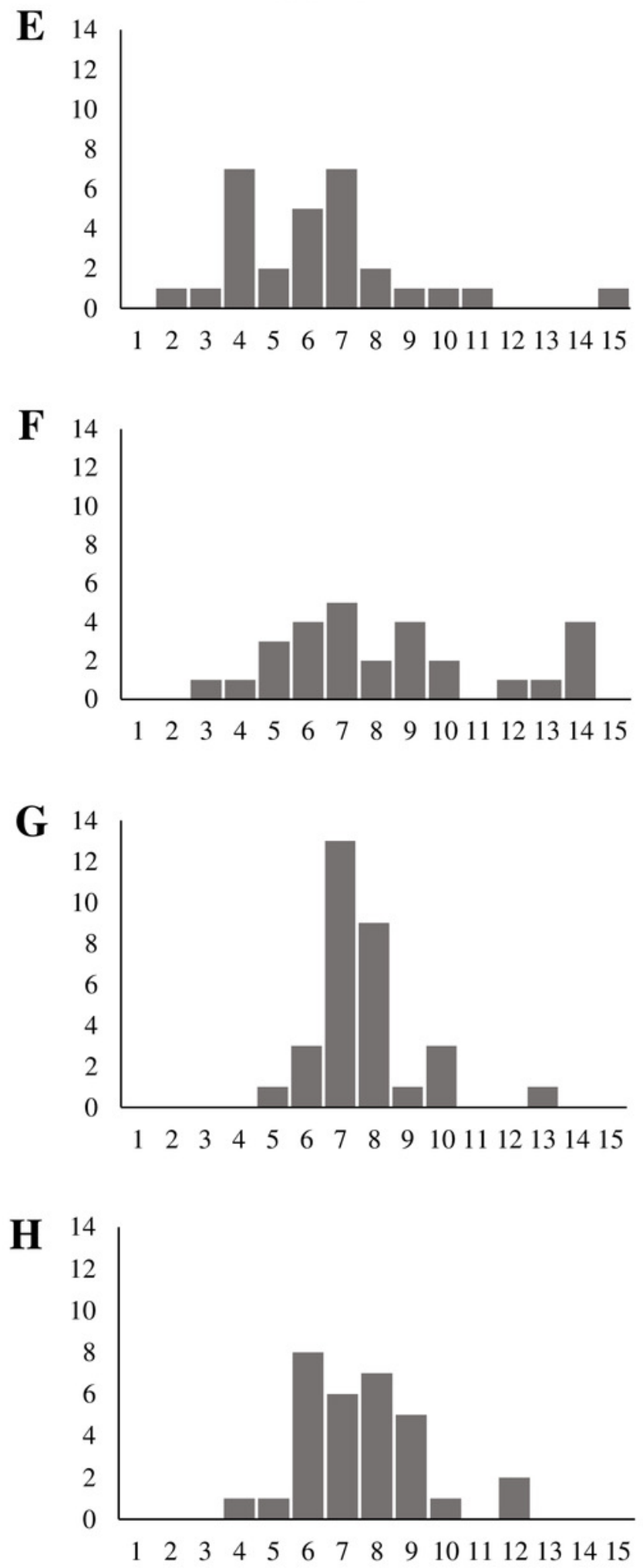

Age (years) 
Figure 8

(A) Observed and (B) smoothed age-length keys for Leptogorgia virgulata colonies.

All four study sites are represented. A, N=102. Colored blocks represent the proportion of corals at that age within the $5 \mathrm{~cm}$ total length bin. 

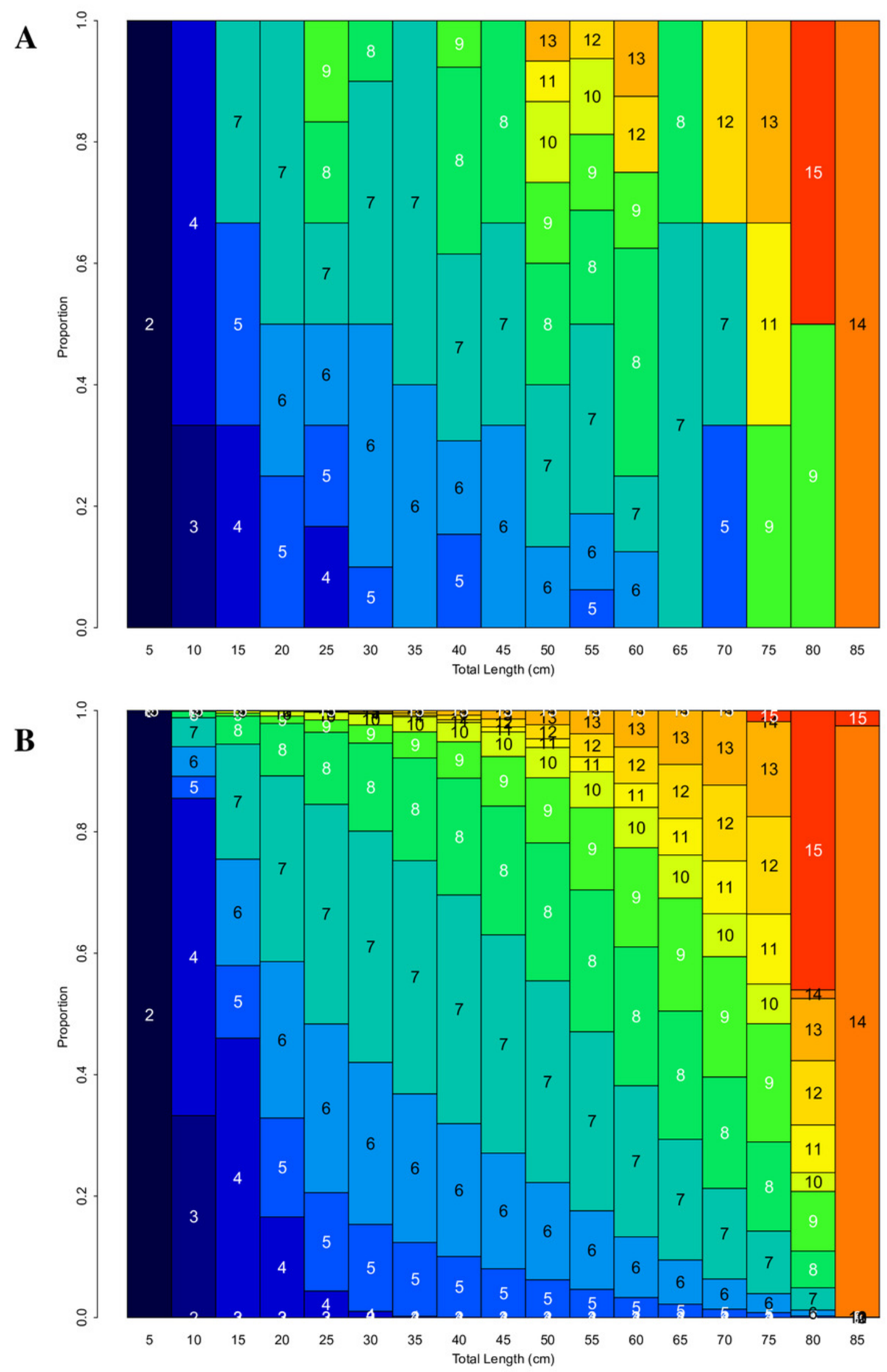
Figure 9

The von Bertalanffy growth model for Leptogorgia virgulata colonies collected from all four study sites.

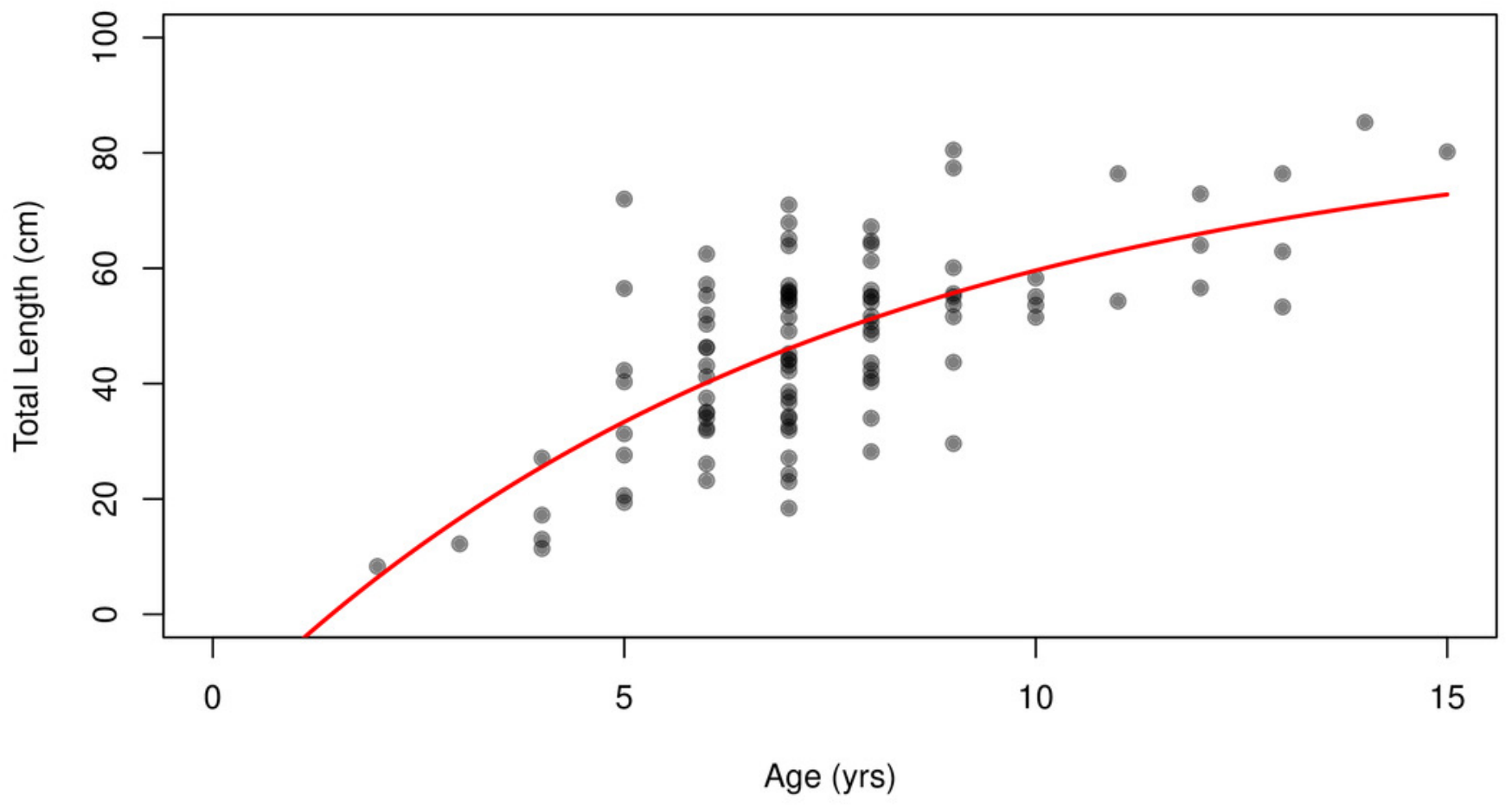




\section{Table 1 (on next page)}

Descriptive information of the four artificial reef study sites in the Mid-Atlantic Bight.

Includes study site name, location, depth $(\mathrm{m})$, date visited, number of corals measured in-situ $\left(N_{I S}\right)$ and number of corals collected $\left(N_{\mathrm{C}}\right)$. 
1

\begin{tabular}{ccccccc}
\hline Study Site & $\begin{array}{c}\text { Latitude } \\
\text { (decimal } \\
\text { degrees, N) }\end{array}$ & $\begin{array}{c}\text { Longitude } \\
\text { (decimal } \\
\text { degrees, W) }\end{array}$ & Depth (m) & Date & $N_{I S}$ & $N_{\mathrm{C}}$ \\
\hline Memorial & 38.290983 & -74.910817 & $17-20$ & $10 / 03 / 2016$ & - & 11 \\
Barge & & & & $08 / 07 / 2017$ & 29 & 13 \\
South Ledges & 38.151100 & -74.946600 & $17-21$ & $08 / 11 / 2017$ & 28 & 26 \\
Sussex Wreck & 38.159000 & -74.944050 & $24-26$ & $08 / 10 / 2018$ & 31 & 29 \\
Boom Wreck & 38.140550 & -74.961767 & $21-24$ & $10 / 01 / 2018$ & 31 & 23 \\
\hline
\end{tabular}




\section{Table 2 (on next page)}

Colony complexity of $L$. virgulata samples from four sites in the Mid-Atlantic Bight.

Bifurcation ratios $\left(R_{b}\right)$ are the number of branches of a given order to the number of branches of the next higher order, and tributary to source ratios $(T / S)$ are the number of tributary branches vs. the number of source branches. T/S ratios were calculated for both $1^{\circ}$ and $2^{\circ}$, primary and secondary, branches. $N$, number of colonies; NS, not significant (One-way ANOVA, $P>0.05$ ). 


\begin{tabular}{ccccc}
\hline Site & $N$ & $\mathrm{R}_{\mathrm{b}}$ & \multicolumn{2}{c}{$\mathrm{T} / \mathrm{S}$ ratios } \\
\cline { 4 - 5 } & & & $1^{\circ}$ & $2^{\circ}$ \\
\hline Memorial Barge & 24 & 3.0 & 0.60 & 0.43 \\
South Ledges & 26 & 2.8 & 0.52 & 0.39 \\
Sussex Wreck & 29 & 2.9 & 0.41 & 0.53 \\
Boom Wreck & 23 & 2.9 & 0.48 & 0.44 \\
Significance & & $\mathrm{NS}$ & $\mathrm{NS}$ & $\mathrm{NS}$ \\
\hline
\end{tabular}




\section{Table 3(on next page)}

Tests of symmetry between age estimates made by readers 1 and 2 .

$\mathrm{df}=$ degrees of freedom, $\chi^{2}=$ chi-square value. $N=102$. 
1

\begin{tabular}{cccc}
\hline Test & df & $\chi^{2}$ & $P$ \\
\hline McNemar & 1 & 0.22 & 0.637 \\
Evans and Hoenig & 1 & 0.22 & 0.637 \\
Bowker & 7 & 7.47 & 0.382 \\
\hline
\end{tabular}

